\title{
6. Logistyczne aspekty handlu elektronicznego
}

Dagmara Zając*

\subsection{Wstęp}

Internet to w powszechnym znaczeniu sieć komputerowa, czyli wiele połączonych ze sobą komputerów. Ta globalna sieć ma obecnie znaczący wpływ na nasze życie: jest źródłem informacji i rozrywki, umożliwia komunikowanie się niezależnie od tego, w jakim miejscu świata znajdują się rozmawiający, ale - co najważniejsze - Internet stał się miejscem prowadzenia biznesu, głównie handlu. Można śmiało postawić hipotezę, że w najbliższej przyszłości przetrwać będą mogły tylko te firmy, które przynajmniej część działalności przeniosą do Internetu. $Z$ tego względu obserwujemy gwałtowny wzrost liczby polskich sklepów internetowych, których może być nawet 10 tysięcy.

Internet jest najbardziej dynamicznie rozwijającym się kanałem dystrybucji polskiego handlu. Według ADV.pl, wartość tego rynku w 2011 r. mogła wzrosnąć nawet o $11 \%$, osiągając ponad $18 \mathrm{mld} \mathrm{zł}$. Trudno się dziwić takim liczbom, skoro co trzeci zakup w Polsce odbywa się w Internecie.

$\mathrm{Na}$ tak szybki rozwój wartości sprzedaży w Internecie i rosnącą liczbę e-sklepów największy wpływ ma niewątpliwie coraz większe przekonanie Polaków do kupowania w sieci. Klienci dostrzegaja ogromne możliwości e-handlu, a z drugiej strony e-sklepy robia wszystko, by sprostać wymaganiom swoich klientów i zapewnić im jak największy komfort zakupów, dając możliwość wyboru sposobu zapłaty, rodzaju przesyłki czy też podglądu stanu magazynowego. W efekcie - działania sklepów internetowych skupiaja się na logistycznej obsłudze klienta.

* Mgr Dagmara Zając - Katedra Marketingu, Wydział Zarządzania Uniwersytetu Łódzkiego, ul. Matejki 22/26, 90-237 Łódź.

${ }^{1}$ http://lead.download.idg.pl/sbwps/b782ce7472f72124a0ff28eb0b451cbb/4f390 3b0/is/Raport_eCommerce_2011.pdf [z dn. 13.02.2012]. 
Celem rozdziału jest przedstawienie aspektów logistycznych zwiazanych z prawidłowym funkcjonowaniem sklepu internetowego. Wyniki badań własnych zostały opracowane na podstawie elektronicznej ankiety, przeprowadzonej na przełomie stycznia i lutego 2012 r. z udziałem ponad 100 e-sklepów. Analiza dotyczyła głównie logistyczno-marketingowego zarządzania e-sklepem.

\subsection{Logistyka w handlu elektronicznym}

\subsubsection{Produkt i cena w Internecie}

Asortyment sklepów internetowych nie jest ograniczony wielkością powierzchni punktów sprzedaży. Przykładem ogromnego wyboru towarów może być oferta księgarni Amazon.com czy polskiego Merlin.pl, które sa w stanie dostarczyć ok. 90\% wydawnictw książkowych, muzycznych i multimedialnych dostępnych w kraju, a ponadto umożliwiaja zakup pozycji, których nakład się wyczerpał i nie sa już dostępne w innych księgarniach lub hurtowniach. O zbliżeniu się do takiej wielkości oferty tradycyjne księgarnie nie moga nawet marzyć. Wyobraźmy sobie, jak ogromna musiałaby być powierzchnia sklepu oferujacego taki wybór towarów i z jakimi kosztami wiązałoby się jej wynajęcie. Klient byłby jednocześnie zmuszony stracić wiele czasu na przemierzanie tak ogromnego sklepu w poszukiwaniu wymarzonej pozycji².

Według Ph. Kotlera produkt to każda rzecz oferowana na rynku nabywcom w celu zwrócenia ich uwagi, nabycia, użytkowania lub konsumpcji, która może zaspokoić określona potrzebę lub pragnienie. $\mathrm{Na}$ podstawie tak szerokiej definicji, za produkt uznajemy zarówno rzecz fizyczna, jak i usługę, osobę, miejsce, organizację, ideę bądź zespół tych elementów ${ }^{3}$.

Osią produktu w koncepcji prezentowanej przez Kotlera jest pożytek, korzyść kupowana przez nabywcę, oferowana przez produkt $w$ formie podstawowej. Wyższe poziomy modelu to ${ }^{4}$ :

- produkt oczekiwany - cechy oczekiwane przez nabywców,

- produkt ulepszony - cechy odróżniające ofertę od konkurentów,

- produkt potencjalny - możliwości rozwoju produktu; to, jaki produkt może być w przyszłości.

2 U. Świerczyńska-Kaczor, P. Kossecki, Wirtualny rynek. Inwestorzy. Przedsiębiorstwa. Klienci, Wyd. Uniwersytetu Humanistyczno-Przyrodniczego Jana Kochanowskiego, Kielce 2008, s. 92.

${ }^{3}$ Ph. Kotler, Marketing. Podręcznik europejski, PWE, Warszawa 2002, s. 615.

${ }^{4}$ T. Maciejowski, Firma w Internecie, Oficyna Ekonomiczna, Kraków 2004, s. 160. 
Kotler uważa, że produkt powinien być analizowany na trzech zasadniczych poziomach (rys. 14). Rdzeń produktu znajduje się w samym centrum produktu całkowitego i oznacza podstawową korzyść lub zdolność produktu do rozwiązania określonego problemu nabywcy, z uwagi na która jest kupowany ${ }^{5}$. Przykładowo, kobieta kupująca sukienkę nie poszukuje tylko czegoś, w co się ubierze, ale oczekuje, że zakupiony produkt przyniesie jej korzyść w postaci lepszego wygląu i zwrócenia na siebie uwagi.

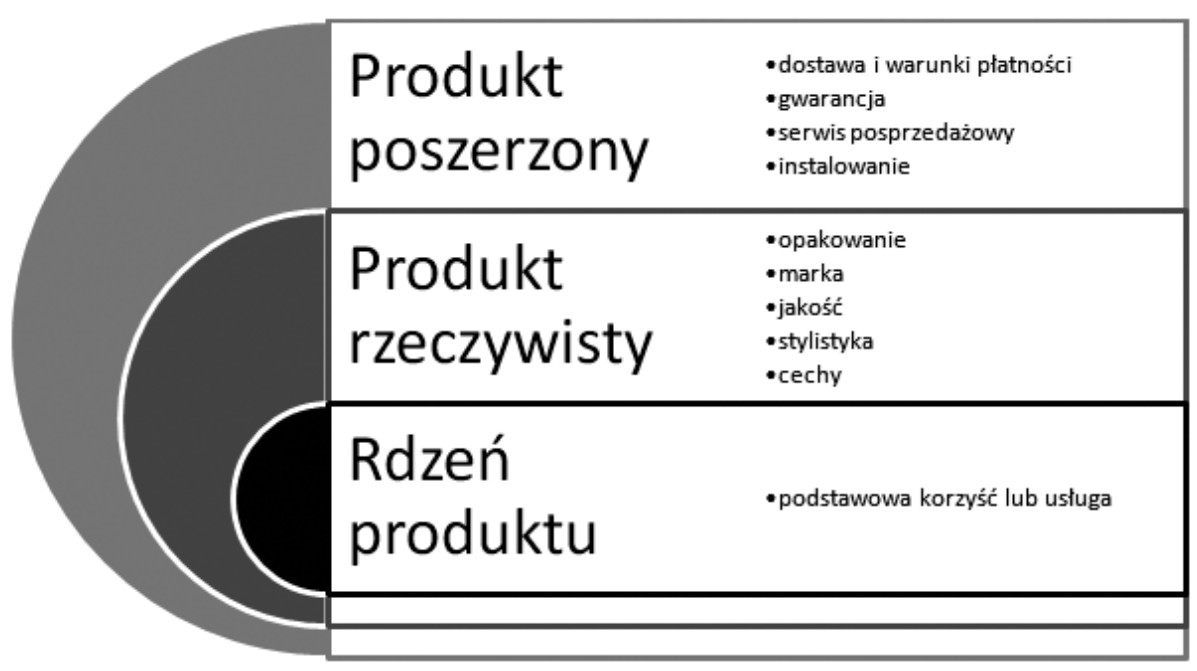

Rysunek 14. Trzy poziomy produktu

Źródło: opracowanie własne na podstawie: Ph. Kotler, Marketing. Podręcznik europejski, PWE, Warszawa 2002, s. 615

Wokół rdzenia produktu budowany jest produkt rzeczywisty, na który składa się pięć elementów: określony poziom jakości produktu, jego specyficzne cechy, stylistyka (np. niestandardowy kształt i kolor), marka i opakowanie ${ }^{6}$. Przykładem produktu rzeczywistego może być odtwarzacz mp3 polskiej marki Vedia, charakteryzujący się niewielkimi wymiarami przy dużej pojemności pamięci i możliwości poszerzenia jej poprzez dokupienie karty pamięci, odpornością na wstrząsy i upadki z dużej wysokości ze względu na dodatkowe silikonowe opakowanie. Ponadto odtwarzacz ma funkcję dyktafonu, radia i możliwość odczytu plików tekstowych.

\footnotetext{
${ }^{5}$ Ph. Kotler, Marketing..., s. 616.

${ }^{6}$ Tamże.
} 
$\mathrm{Na}$ produkt poszerzony składaja się dodatkowe korzyści i usługi związane z dana oferta ${ }^{7}$. Wracając do przykładu odtwarzacza mp3 producent oferuje coś więcej niż możliwość słuchania i nagrywania muzyki w każdych warunkach i o każdej porze. Produkt posiada 2-letnia gwarancję z opcja jej przedłużenia do 5 lat za dopłatą oraz możliwość aktualizowania oprogramowania odtwarzacza poprzez ściągnięcie za darmo najnowszej wersji programu ze strony internetowej producenta wraz z instrukcja, jak takiej aktualizacji dokonać.

Odpowiedź na pytanie, dlaczego warto wspomnieć o produkcie w kontekście logistyki e-commerce jest prosta - bez produktu nie byłoby logistyki. Zadaniem logistyki jest dostarczenie odpowiedniego produktu klientowi. W odniesieniu do zakupów internetowych logistyka odgrywa rolę nadrzędna, gdyż warunki i szybkość dostawy są wartościa dodana do produktu, często mająca decydujący wpływ na decyzje zakupowe. Logistyka jest tu niczym innym jak produktem poszerzonym.

Z logistyką silnie związana jest także klasyfikacja produktów dostępnych w Internecie, gdyż od ich rodzaju zależy dostawa towaru do klienta. Zasadniczo wyróżnia się dwa rodzaje takich produktów: produkty tradycyjne i produkty internetowe, jednak w nowoczesnej gospodarce oba typy produktów zaczynaja się wzajemnie przenikać, tworząc trzeci typ produktu - produkty mieszane.

Przykładem produktu czysto internetowego może być program komputerowy napisany i dystrybuowany wyłącznie w sieci lub grafika wystawiona do sprzedaży na stronie internetowej ${ }^{8}$. Rynek wirtualny jest naturalnym środowiskiem sprzedaży produktów informacyjnych, czyli produktów, które można zapisać w formie bitów, np. elektronicznych książek, baz danych, pism, filmów, portali informacyjnych. Produkty te moga być dostarczane bezpośrednio i natychmiast przez Internet użytkownikom, bez konieczności ich fizycznego transportu9. Jedyne, co jest potrzebne sprzedawcy, to swego rodzaju "magazyn" plików, jakim jest serwer internetowy.

Internet stwarza olbrzymie możliwości różnicowania produktów informacyjnych dla różnych segmentów rynku, np. dostawca encyklopedii internetowej może oferować jej podstawowa, tanią wersję uczniom szkół podstawowych oraz wersję najobszerniejszą - bibliotekom. Inne sposoby różnicowania produktów informacyjnych opierają się na odmienności interfejsu użytkownika (dostępność różnych opcji programu

7 Tamże.

${ }^{8}$ T. Maciejowski, Firma w Internecie, s. 160.

${ }^{9}$ C. Shapiro, H. R. Varian, Potęga informacji. Strategiczny przewodnik po gospodarce sieciowej, Helion, Gliwice 2007, s. 69-73. 
w zależności od potrzeb użytkowników), czasu dostarczania produktu (np. sprzedaż najnowszych utworów muzycznych przed premiera płyty) czy rozdzielczości obrazu (np. różnicowanie ceny w zależności od jakości obrazu przez firmy oferujące sprzedaż zdjęć) ${ }^{10}$.

Produkty informacyjne (np. konta pocztowe, programy komputerowe) cechuje ponadto właściwość zwiększania ich wartości dla końcowego użytkownika w zależności od rosnącej liczby użytkowników, czyli osiaggania efektu sieciowego ${ }^{11}$. Oznacza to, że użyteczność produktów dla klienta rośnie w zależności od używania tego produktu przez innych użytkowników, np. w sytuacji jednakowego oprogramowania wykorzystywanego przez różnych użytkowników znika obawa o trudność wzajemnej wymiany plików ${ }^{12}$.

Produktem tradycyjnym jest dobro istniejące $w$ realnej rzeczywistości, dostępne także bez pośrednictwa Internetu w tradycyjnym sklepie. To wszelkie produkty materialne, zaczynając od dostępnych już w Internecie produktów żywnościowych ${ }^{13}$, poprzez książki, kosmetyki i ubrania, kończąc na sprzęcie AGD/RTV.

Nie ulega watpliwości, że Internet wywiera ogromny wpływ na produkty, ze względu na silną konkurencję między handlem tradycyjnym a wygodnym i szybkim handlem internetowym. Jednak, mimo ogromnego wyboru produktów w Internecie, nie udaje się zwirtualizować sprzedaży niektórych produktów. Na rynku wirtualnym brak jest możliwości świadczenia usług powstających w bezpośrednim kontakcie z nabywcą lub jego rzeczami i mających bezpośredni efekt, np. fryzjerskich, prania chemicznego ${ }^{14}$. Przykładami innych produktów, których dystrybucja napotyka na trudności w Internecie $\mathrm{sa}^{15}$ :

- towary delikatne, które moga ulec uszkodzeniu w czasie dostawy,

- towary wymagające fizycznego oglądu ze względu na ich jakość, kolor, zapach, wrażenia dotykowe itp.,

- towary nietrwałe, łatwo psujace się,

- towary o wysokiej cenie, za wyjątkiem zestandaryzowanych towarów, których jakości konsument może być pewien.

10 Tamże.

11 Tamże, s. 25.

12 U. Świerczyńska-Kaczor, P. Kossecki, Wirtualny rynek..., s. 92.

13 Sprzedaż żywności przez Internet oferuje w największych polskich miastach np. sieć delikatesów Alma. Klient składa zamówienie przez Internet, a świeże towary są mu dostarczane do domu w ciągu kilku godzin.

${ }^{14}$ U. Świerczyńska-Kaczor, P. Kossecki, Wirtualny rynek..., s. 93.

${ }^{15}$ P. Bickerton, M. Bickerton, U. Pardesi, Marketing w Internecie, Gdańskie Wyd. Psychologiczne, Gdańsk 2006, s. 209-210. 
Na trudności w sprzedaży internetowej napotykaja te produkty, które konsument kupuje, opierając się na wrażeniach dotykowych, np. kobieta nie może w pięknym otoczeniu przymierzyć brylantowej kolii i zobaczyć, jak pasuje ona do jej ulubionej sukni i dlatego sklepy internetowe sprzedające biżuterię nie zagrażają tradycyjnym salonom jubilerskim. Podobny aspekt występuje w przypadku większości towarów luksusowych - w sytuacjach sprzedaży, w których klient potrzebuje emocjonalnej więzi z wybranym towarem, a także satysfakcji związanej $z$ dokonaniem zakupu i warunkami, w jakich tego dokonał ${ }^{16}$.

Wraz z rozwojem Internetu zanikaja zwyczajowe formy niektórych produktów, czego przykładem mogą być bilety lotnicze. Przeobraża się również oferta poszczególnych branż, np. branży fotograficznej (większość zdjęć w zapisie cyfrowym), usług finansowych (tradycyjne konto oszczędnościowe z dostępem do Internetu). Sa to właśnie przykłady produktów mieszanych, mających cechy zarówno produktu tradycyjnego, jak i internetowego. Wracając do przykładu odtwarzacza mp3 - można uznać, iż jest on produktem mieszanym, bo jego aktualizacji dokonuje się przez Internet. Takie produkty wymagaja zarówno dystrybucji fizycznej - dostarczenia odtwarzacza klientowi, czy to poprzez kuriera, czy przez zwykły zakup w sklepie, jak i dystrybucji cyfrowej zaktualizowanego oprogramowania.

Podsumowując charakterystykę produktów dostępnych w Internecie, należy przedstawić trzy najważniejsze cechy współczesnych e-produktów, mając na myśli zarówno produkty tradycyjne, jak i te stricte wirtualne ${ }^{17}$ :

- nasycenie informacyjne,

- skrócony cykl życia produktów,

- możliwość kompozycji na żądanie.

J. Wielki stwierdza, że najważniejszym wyróżnikiem produktów dostępnych w Internecie jest możliwość ich informacyjnego nasycenia ${ }^{18}$. Internet posiada wręcz nieograniczoną pojemność, dzięki której dostawcy towarów i usług moga do woli mnożyć informacje na swoich stronach internetowych, umieszczając tam opisy produktów, zdjęcia, filmy, instrukcje montażu i użytkowania, opinie innych użytkowników i specjalistów ${ }^{19}$.

${ }^{16}$ U. Świerczyńska-Kaczor, P. Kossecki, Wirtualny rynek..., s. 93.

${ }_{17}$ T. Maciejowski, Firma w Internecie, s. 161.

18 J. Wielki, Elektroniczny marketing poprzez Internet, PWN, Warszawa-Wrocław 2000, s. 105.

${ }^{19}$ T. Maciejowski, Firma w Internecie, s. 162. 
Przykładem takiego wykorzystania Internetu do sprzedaży tradycyjnych produktów AGD/RTV może być sklep Euro, mający swoją stronę internetowa pod adresem www.euro.com.pl. Klient sklepu ma możliwość obejrzenia w Internecie całego asortymentu sklepu, porównania ze sobą maksymalnie czterech produktów oraz zapoznania się z opiniami osób będących już użytkownikami produktu. Ponadto zna cenę towaru i oferowane usługi dodatkowe ${ }^{20}$. Co ważne, jeśli klient obawia się kupować w sieci, może - „uzbrojony" w wiedzę o produkcie - udać się do najbliższego sklepu i dokonać zakupu w tradycyjny sposób.

Tradycyjny cykl życia produktu obejmuje pięć zasadniczych faz ${ }^{21}$ (rys. 15):

1) rozwój produktu,

2) wprowadzenie,

3) wzrost,

4) dojrzałość,

5) spadek.

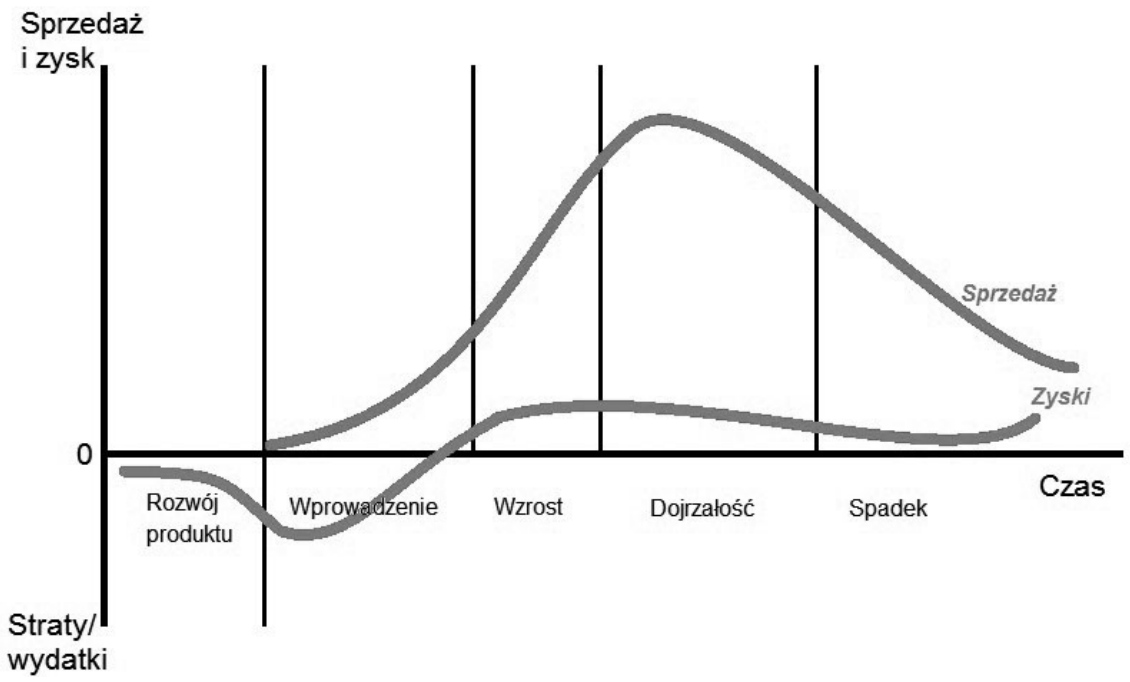

Rysunek 15. Cykl życia produktu

Źródło: jak do rys. 14, s. 687

20 Jedna z usług dodatkowych oferowanych w sklepie Euro jest wniesienie nowego sprzętu do domu, jego instalacja i zabranie do utylizacji starego urządzenia.

${ }^{21} \mathrm{Ph}$. Kotler, Marketing..., s. 686. 
Internet bardzo silnie oddziałuje na cykl życia produktu - dzięki znacznemu przyspieszeniu obiegu informacji dochodzi do obniżenia barier wejścia na rynek. W rezultacie cykl życia produktów znacznie się skraca. Wprowadzane na rynek dobra i usługi sa szybko identyfikowane przez konkurencję, co przyczynia się często do skrócenia czasu trwania fazy wzrostu, a także fazy dojrzałości.

Produkt musi być często modyfikowany, w przeciwnym razie będzie szybko kopiowany przez konkurencję, co ostatecznie może doprowadzić do utraty klientów przez oferujaca go firmę22.

Nowoczesna technologia informatyczna umożliwia tworzenie produktów zindywidualizowanych, oferowanych na życzenie - można tu pokusić się o określenie ich mianem produktów na żądanie (product on demand $)^{23}$. Konstrukcja produktu na żądanie przy pomocy Internetu może być również realizowana przez dostawców dóbr tradycyjnych, czego przykładem jest oferta Opla. Na stronie www.opel.pl internauta ma możliwość skonfigurowania własnego samochodu. Po wybraniu modelu wskazuje silnik, rodzaj skrzyni biegów, tapicerkę czy kolor nadwozia. Jednocześnie po każdym wyborze aktualizuje się automatycznie cena tak skonfigurowanego samochodu.

Według T. Gajewskiej do najważniejszych atutów internetowej formy sprzedaży zaliczane są: niższa cena w porównaniu do cen sklepów tradycyjnych i oszczędność czasu spowodowana brakiem konieczności wychodzenia $z$ domu ${ }^{24}$.

Pojęcie ceny można rozpatrywać w dwóch zakresach ${ }^{25}$ :

- węższym - cena jest suma pieniędzy żądanych za produkt lub usługę,

- szerszym - cena to suma wszystkich wartości, jakie konsument wymienia w zamian za posiadanie lub użytkowanie produktu lub usługi.

Specyfika Internetu wpływa na ceny i sposoby ich ustalania. Cena produktu w Internecie jest zazwyczaj niższa, co wynika z faktu niższych kosztów operacyjnych e-sklepu. Klient internetowy "sam się obsługuje" i sam dokonuje płatności, a system komputerowy bez udziału człowieka przetwarza te dane, informujac pracownika sklepu, jaki produkt i dokąd należy wysłać. Można powiedzieć, że w gestii samego e-sklepu pozostaje tylko logistyka i to właśnie obsługa logistyczna generuje największe koszty oraz wpływa na końcową cenę produktu.

22 T. Maciejowski, Firma w Internecie, s. 163.

23 Tamże.

${ }^{24}$ T. Gajewska, Logistyczne aspekty wynikające $z$ funkcjonowania handlu elektronicznego w ujęciu teorii i praktyki, "LogForum" 2009, t. 5, z. 3, nr 4, s. 2; wersja elektroniczna: www.logforum.net/pdf/5_3_4_09.pdf, s. 2.

25 Ph. Kotler, Marketing..., s. 742. 
Cena była do niedawna głównym czynnikiem warunkującym decyzje zakupowe. Jednak w ciągu ostatnich kilkudziesięciu lat dla kupujacych nabrały znaczenia czynniki pozacenowe, takie jak jakość czy choćby opakowanie produktu. W XXI w. w kontekście rozwoju e-commerce na pierwszym miejscu znalazła się logistyka, mająca zapewnić najwyższy poziom obsługi klienta przy możliwie najniższych kosztach, rozumiany tutaj jako najszybsza i najtańsza dostawa. Cena samego produktu jest tylko częścia kosztów, jakie ponosi kupujący, ponieważ musi on także zapłacić za dostawę towaru do domu. Można powiedzieć, że płaci on za wygodę dokonania zakupu bez ruszania się z domu.

\section{Cena dla kupującego = cena produktu + koszt dostawy}

Na koszt dostawy składa się koszt opakowania produktu, tak by nie uległ on zniszczeniu w transporcie, koszt samego transportu (często zależny od czasu oczekiwania na przesyłkę) i ewentualne ubezpieczenie towaru w przypadku towarów o dużej wartości.

Klienci zazwyczaj sami dokonuja wyboru formy dostawy zakupionego produktu do domu. W Polsce wciąż najczęściej wybierana forma dostawy są przesyłki Poczty Polskiej26, ponieważ są one najtańsze.

Aby skłonić klienta do zakupów w Internecie, rozpowszechnioną praktyką jest stosowanie różnego rodzaju promocji cenowych, takich jak ${ }^{27}$ :

- promocje za zakup w sieci - polegajace na wynagrodzeniu internauty za sam fakt dokonania zakupu w wirtualnej placówce zamiast w tradycyjnym sklepie ${ }^{28}$,

- promocje okresowe - obniżki cen trwające przez określony czas, mające zachęcić internautów do składania zamówień np. w okresie przedświątecznym czy wakacyjnego zastoju,

- rabaty - udzielane zazwyczaj ze względu na wielkość złożonego zamówienia. Moga to być rabaty gotówkowe (np. cena niższa o 10\%) lub też udzielane na zakup kolejnego produktu (np. możliwość zakupienia jeszcze jednej książki za połowę ceny) ${ }^{29}$,

${ }^{26}$ Internet Standard, e-Commerce 2010. Badanie polskich sklepów internetowych, wrzesień 2010.

27 T. Maciejowski, Firma w Internecie, s. 173.

28 Taki zabieg stosuje często wspomniany już sklep Euro - niektóre produkty sa objęte promocja tylko $\mathrm{w}$ Internecie, $\mathrm{w}$ tradycyjnym sklepie produkt nie jest objęty promocja cenowa.

${ }^{29} \mathrm{~W}$ tym wypadku, gdy proponowany jest konkretny produkt, mówimy o promocji krzyżowej - promocja cenowa określonego produktu A przy zakupie produktu B. 
- bezpłatne usługi towarzyszące - zwykle również zależne od wielkości złożonego zamówienia.

Na witrynach sieciowych sklepów często spotykamy formułę typu "za zakupy powyżej kwoty X zł dostawa gratis". To właśnie przykład bezpłatnej usługi towarzyszącej. W ten sposób konkuruje ze soba coraz więcej sklepów internetowych, biorąc na siebie koszty logistyki pod warunkiem, że klient dokona odpowiednio dużych zakupów. Klient płaci tylko za zakupione produkty.

Powyższe analizy pokazuja, że równie ważnym czynnikiem dla internetowych konsumentów obok atrakcyjnej ceny jest oszczędność czasu. Wynika ona nie tylko z możliwości szybkiego złożenia zamówienia, ale również z aspektu logistycznego, tj. dostarczenia w jak najkrótszym czasie zamówionego towaru klientowi. Odbiorca za pośrednictwem przeglądarki internetowej ma możliwość obejrzenia towaru bez wychodzenia z domu. Ma przy tym okazję do łatwego i szybkiego zebrania potrzebnych informacji, a gdy zdecyduje się na zakup - krótkiego oczekiwania na zamówiony produkt. Wpływ na ocenę jakości procesu zakupu ma wysoka dbałość o opakowanie i zabezpieczenie towaru wysyłanego do klienta ${ }^{30}$.

\subsubsection{Proces realizacji internetowego zamówienia}

Na tradycyjnym rynku wyróżnia się następujące etapy sprzedaży ${ }^{31}$ :

1) poszukiwanie klientów,

2) otwarcie sprzedaży,

3) diagnoza potrzeb klienta,

4) prezentacja oferty,

5) rozwiewanie obiekcji i zastrzeżeń klienta, finalizacja,

6) podtrzymanie kontaktu sprzedażowego.

W procesie wirtualnej sprzedaży etapy otwarcia sprzedaży, diagnozy potrzeb, prezentacji oferty czy rozwiewania obiekcji przenikają się wzajemnie i są trudne do jednoznacznego wyodrębnienia. Na rys. 16 przedstawiono przebieg procesu sprzedaży na rynku wirtualnym, odnosząc go do tradycyjnego modelu prowadzenia rozmowy sprzedażowej.

${ }^{30}$ A. Kawa, Logistyczna obsługa handlu elektronicznego - problemy i rozwiązania, „CEO - Magazyn Kadry Zarządzającej” 2007, nr 11.

31 U. Świerczyńska-Kaczor, P. Kossecki, Wirtualny rynek..., s. 98. 

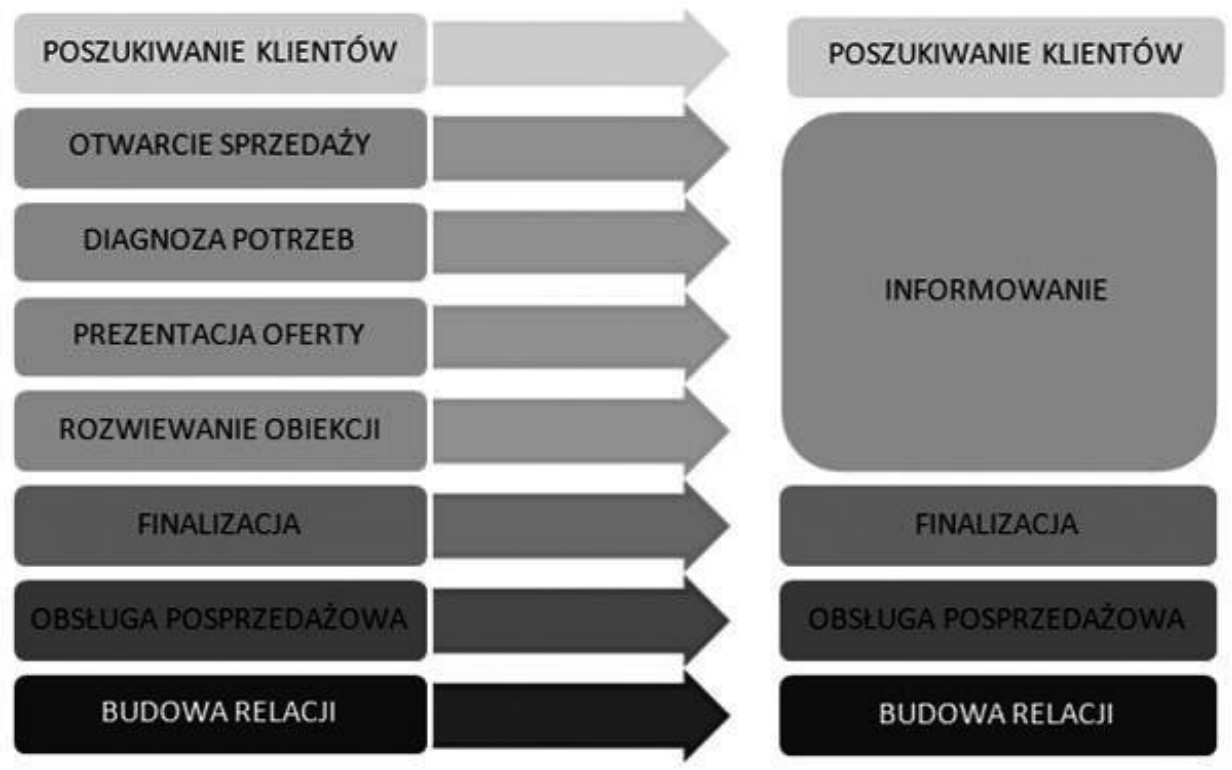

Rysunek 16. Porównanie etapów sprzedaży na rynku wirtualnym i tradycyjnym Źródło: opracowanie własne na podstawie: U. Świerczyńska-Kaczor, P. Kossecki, Wirtualny rynek. Inwestorzy. Przedsiębiorstwa. Klienci, Wyd. Uniwersytetu Humanistyczno-Przyrodniczego Jana Kochanowskiego, Kielce 2008, s. 99

\section{Poszukiwanie klientów}

$\mathrm{Na}$ tradycyjnym rynku sprzedawcy dysponują wieloma narzędziami aktywnego docierania do klientów: od nawiązywania kontaktu na podstawie numerów z książki telefonicznej, poprzez informacje udzielone przez dotychczasowych klientów, po pozyskiwanie danych klientów w trakcie różnego rodzaju wydarzeń (np. prezentacji w firmie, na festynie) $)^{32}$.

Na rynku internetowym szukanie klientów opiera się na właściwej całościowej komunikacji, m.in. na dobrze zaprojektowanej stronie internetowej, wysyłaniu e-maili prezentujących firmę i jej ofertę, reklamie internetowej, zamieszczeniu ofert w porównywarkach cen. Metodami pozyskiwania danych klientów sa $^{33}$ :

- zbieranie adresów e-mailowych klientów bezpośrednio z witryny internetowej firmy i opracowanie listy e-mailingowej,

\footnotetext{
32 U. Świerczyńska-Kaczor, P. Kossecki, Wirtualny rynek..., s. 99.

${ }^{33}$ P. Bickerton, M. Bickerton, U. Pardesi, Marketing w Internecie, s. 288-291.
} 
- zamieszczenie na stronie autorespondera, czyli mechanizmu, w którym klienci zamawiaja poczta elektroniczną określone informacje,

- wysyłanie informacji na istniejace witryny,

- zbieranie adresów e-maili z grup dyskusyjnych,

- zakup listy e-mailingowej.

Pozyskiwanie klientów jest łatwiejsze w momencie, gdy witryna sklepu ma wysoką pozycję na liście wyników wyszukiwarek, np. Google. Jeśli internauta, wpisując dowolne zapytanie, w jednym z pierwszych linków znajdzie odniesienie do strony danego dostawcy, to prawdopodobieństwo nawiązania kontaktu znacznie się zwiększa - z wyszukiwarek korzysta $92 \%$ internautów, z czego zdecydowana większość z nich nie sprawdza linków poza trzecia stroną wyników ${ }^{34}$.

\section{Informowanie}

W pierwszych kilku minutach tradycyjnego spotkania sprzedażowego następuje nawiązanie kontaktu pomiędzy sprzedającym a kupujacym. Zadaniem sprzedawcy jest dopasowanie swojego zachowania do sposobu komunikacji nabywcy - jego ekspresyjności, słownictwa, gestykulacji.

Na tradycyjnym rynku sprzedawca poprzez zadawanie pytań ustala potrzeby i oczekiwania klienta w zakresie produktu, serwisu, sposobu dostawy, obaw związanych z jego użytkowaniem. Następnym zadaniem sprzedawcy jest poprowadzenie dobrej prezentacji produktu w odwołaniu do zdiagnozowanych potrzeb klienta oraz w sposób akcentujacy indywidualne korzyści, jakie klient odniesie z zakupu. Wielu klientów zgłasza w trakcie sprzedaży zastrzeżenia dotyczące produktu, jego użytkowania, jak również zastrzeżenia mające charakter emocjonalny. Rozwiewanie obiekcji klienta stanowi zatem kolejny etap prowadzenia rozmowy handlowej35.

W handlu internetowym, gdy transakcja w całości przeprowadzana jest na wirtualnym rynku, funkcję sprzedawcy pełni witryna dostawcy, będąca podstawowym źródłem informacji dla konsumenta. Projektowanie dobrej witryny sprzedażowej wymaga odpowiedzi na następujace pytania 36 :

- jak ma wyglądać interakcja pomiędzy klientami a marką na rynku wirtualnym?

\footnotetext{
${ }^{34}$ A. Mitko, M. Gałecki, Dobieranie słów w e-PR, "Marketing w Praktyce" 2006, nr 9.

35 U. Świerczyńska-Kaczor, P. Kossecki, Wirtualny rynek.., s. 100.

${ }^{36}$ P. Bickerton, M. Bickerton, U. Pardesi, Marketing w Internecie, s. 172.
} 
- jakie czynniki powoduja zbudowanie dobrej, wysokiej jakości relacji z klientami?

- jak inicjować i podtrzymywać dialog w Internecie?

- jakiego rodzaju doświadczenia internetowe wzmocnią postrzeganie mojej marki przez klientów?

Poszczególne elementy witryny mają różne znaczenie w procesie sprzedaży, np. spersonalizowane powitanie służy budowaniu dobrego kontaktu z klientem, natomiast umieszczenie zakładki „Pomoc" lub "Najczęściej zadawane pytania" pozwala rozwiać wątpliwości klientów.

Wirtualni dostawcy dysponuja możliwościa zbudowania indywidualnej relacji z każdym klientem. Wykorzystanie w e-sprzedaży baz danych zarówno na poziomie operacyjnym, jak i strategicznym pozwala na prowadzenie marketingu partnerskiego, opartego na personalizacji ofert. Szczególnie na rynku internetowym widoczna jest prawda, że "rynek dzieli się nie na segmenty, lecz na indywidualnych nabywców"37. Personalizacja kontaktu umożliwia lepsze dostosowanie kolejnych ofert do profilu danego nabywcy, np. poprzez wprowadzenie zmian w wygladzie witryny zgodnych ze wzorami nawigacji klienta i schematem poprzednich zakupów oraz dostosowanie polityki rabatowej, przyjmując jako podstawę wcześniejsze zakupy i poszukiwania klienta ${ }^{38}$.

Szczegółowość zamieszczanych na stronie WWW informacji uzależniona jest od charakteru sprzedawanego produktu oraz od tego, czy firma posiada zaplecze $\mathrm{w}$ postaci tradycyjnych kanałów dystrybucji. Dla firm sprzedających zarówno w sieci, jak i na tradycyjnym rynku zamieszczanie obszernych informacji na stronach internetowych paradoksalnie może się wiązać z niebezpieczeństwem utraty klientów, jeśli firma dostatecznie szybko nie potrafi nawiązać z nimi bezpośredniego kontaktu.

Charakter sprzedawanego produktu wyznacza ramy emocjonalności i racjonalności przekazu zawartego na witrynie. Dla produktów kupowanych racjonalnie, jak np. lodówka, ksero, podstawowe znaczenie będą miały szczegółowe informacje techniczne związane z produktem, natomiast dla produktów kupowanych emocjonalnie, np. perfum, filmów itp., istotne znaczenie maja elementy peryferyjne przekazu, m.in. bohater reklamy, muzyka, ciekawa kolorystyka, ekspozycja logo ${ }^{39}$. A. Sznajder ze względu na przekaz zawarty na witrynach wyodrębnił wi-

${ }^{37}$ I. H. Gordon, Relacje z klientem. Marketing partnerski, PWE, Warszawa 2001, s. 30.

38 J. Dyche, CRM. Relacje z klientami, Helion, Gliwice 2002, s. 51.

39 U. Świerczyńska-Kaczor, P. Kossecki, Wirtualny rynek.., s. 105. 
tryny emocjonalno-informacyjne, emocjonalne, informacyjne oraz witryny podstawowe ${ }^{40}$.

\section{Realizacja zamówienia}

Dobrze poprowadzona sprzedaż kończy się przyjęciem od klienta zamówienia. Na rynku internetowym o finalizacji zamówienia decyduje klient, wypełniając odpowiednie formularze zamówienia, wybierając formę płatności i podając adres wysłania towaru. Zachęcaniu klienta do finalizacji służy ${ }^{41}$ :

- wyraźne zaznaczenie koszyka zakupu,

- wyjaśnienie procesu składania zamówienia,

- możliwość wydrukowania wysłanego formularza zamówienia bezpośrednio po zakończeniu transakcji,

- zapewnienie bezpieczeństwa płatności.

Realizację zamówienia kończy dostarczenie towaru klientowi, szerzej opisane w podrozdziale 6.2.5. Dystrybucja fizyczna i płatności.

\section{Obsługa posprzedażowa}

Obsługa posprzedażna klienta obejmuje m.in. rozpatrywanie zgłaszanych reklamacji (problemy z dostawa, uszkodzenia produktu, produkt niezgodny ze złożonym zamówieniem) oraz rozpatrywanie gwarancji zapewnianych przez producenta.

Wiele sklepów pomija ten obszar działania firmy. Badania przeprowadzone w 1999 r. przez Federalną Komisję Handlu Stanów Zjednoczonych wskazały, że zaledwie $26 \%$ firm bioracych udział w sondażu zamieściło na swoich witrynach informacje o możliwości zwrotu pieniędzy, a jedynie $9 \%$ sklepów opublikowało warunki odwołania ${ }^{42}$. W sytuacji, gdy klient dokonuje zwrotu zakupionego towaru, istotne sa dwa aspekty: zagwarantowanie samego prawa zwrotu oraz zapewnienie odpowiedniej logistyki umożliwiającej jego dokonanie ${ }^{43}$.

Gwarancji i rękojmi moga udzielać zarówno dostawcy internetowi, jak i strony trzecie. W przypadku umożliwienia korzystania z gwarancji i reklamowania wadliwych produktów najważniejszy jest czas reakcji oraz wygoda dla kupującego. Jeśli nie jest możliwe oddanie towaru czy jego naprawienie za pośrednictwem Internetu (tak jak to ma miejsce w przypadku choćby programów komputerowych), to ważnym ele-

\footnotetext{
${ }^{40}$ A. Sznajder, Marketing wirtualny, Oficyna Ekonomiczna, Kraków 2002, s. 116-119.

${ }^{41}$ U. Świerczyńska-Kaczor, P. Kossecki, Wirtualny rynek..., s. 106.

${ }^{42}$ P. Bickerton, M. Bickerton, U. Pardesi, Marketing w Internecie, s. 176.

${ }^{43}$ U. Świerczyńska-Kaczor, P. Kossecki, Wirtualny rynek.., s. 107.
} 
mentem jest posiadanie odpowiedniego zaplecza zapewniajacego serwis czy możliwość zwrotu towaru. Takim zapleczem dysponuja firmy prowadzące działalność także przy pomocy tradycyjnych kanałów dystrybucji. Klient może np. oddać wadliwy towar do najbliższego sklepu danej sieci. Rozwiązanie to ogranicza koszty klienta związane z samym odsyłaniem produktu, np. pocztą kurierską ${ }^{44}$.

\section{Budowa relacji}

Pozyskanie nowego klienta jest siedmiokrotnie droższe od utrzymania dotychczasowego, dlatego tak ważna jest zarówno dla tradycyjnych sklepów, jak i tych internetowych lojalność stałych klientów, której podstawa jest komunikacja z klientem i bieżące śledzenie jego preferencji. Niezbędne stało się wykorzystanie przez e-commerce narzędzi, które w tradycyjnym handlu są znacznie trudniejsze do zastosowania. Oszczędzając czas nabywcy, można, poprzez odpowiednie kwestionariusze lub śledzenie jego ścieżki poruszania się po Internecie, zebrać dokładne dane na jego temat. Pozwala to na budowanie i stałe aktualizowanie bazy danych. W tym sieć daje ogromną przewagę. Firma dysponując informacją o potrzebach i preferencjach, może przedstawić klientowi właściwą ofertę w określonym miejscu i czasie ${ }^{45}$.

Informowanie e-klientów za pomoca poczty elektronicznej o nowościach pojawiajacych się w sklepie, promocjach oraz wysyłanie światecznych i urodzinowych życzeń to w dzisiejszych czasach standard. E-sklepy wychodząc naprzeciw wymaganiom, tworza profile na portalach społecznościowych i angażuja swoich klientów do czynnego udziału w budowaniu świadomości marki.

Jednak sam marketing nie jest gwarantem sukcesu w sieci, gdyż e-klient stał się mniej wrażliwy na kierowane do niego reklamy i świadomy ich celowości. Można zaryzykować stwierdzenie, że w XXI w. dla konsumenta największą wartość ma czas. Jak już wspomniano, charakterystyczne dla internetowych zakupów jest odroczenie konsumpcji, tzn. towar dostarczany jest do konsumenta nawet kilka dni po jego zamówieniu, a ponadto klient nie ma możliwości fizycznego obejrzenia produktu. Dlatego tak ważna staje się logistyka e-commerce.

Dlaczego logistyka odgrywa tak ważna rolę w procesie internetowych zakupów? Odpowiedź zawiera się w podstawowych zasadach logi-

44 Tamże.

45 P. Drygas, Lojalność klienta w wirtualnym biznesie, [w:] A. Tubielewicz (red.), Electronic commerce - gospodarka XXI wieku, Wyd. Politechniki Gdańskiej, Gdańsk 2001, s. 41. 
styki, tzw. 7W ${ }^{46}$. Zakupów w Internecie może dokonywać ogromna liczba osób jednocześnie, dlatego to na sprzedawcy spoczywa obowiązek, by każdy z zamawiających otrzymał dokładnie to, co zamawiał, zgodnie z warunkami zakupu określonymi przez sklep. Współcześni klienci sa mało tolerancyjni na pomyłki sklepu, typu pomylone zamówienia lub kolor zamawianego towaru. Coraz częściej to sprzedający jest obwiniany za opóźnienia w dostawie przesyłki, często niewynikające z jego winy, tylko firmy kurierskiej, dlatego logistyka jest tak istotna we współczesnym e-biznesie.

\subsubsection{Zaopatrzenie e-sklepu}

Podobnie jak tradycyjny sklep, tak samo sklep internetowy, by prowadzić swoja działalność, musi zaopatrzyć się w towary sprzedawane później w sieci. Internet jest bardzo przydatnym narzędziem w organizacji procesów logistyki dostaw. Znacznie poprawia i przyspiesza przepływ informacji między dostawca a odbiorcą: firma jest w stanie na bieżąco kontrolować oferty dostawców, może im również udostępnić informacje o własnych zapasach. Przedsiębiorstwa internetowe, poszukując źródeł tanich dostaw, coraz częściej korzystaja z elektronicznych platform handlowych lub buduja własne systemy wspierania sprzedaży przez Internet. Wszystko to prowadzi do optymalizacji logistyki dostaw, a co za tym idzie - powoduje znaczne oszczędności ${ }^{47}$.

Dzięki Internetowi e-sklep jest w stanie na bieżąco orientować się w ofertach dostawców. Niekiedy firma-dostawca udostępnia zamawiającym swoją bazę danych, dzięki czemu mogą oni stale kontrolować możliwości organizacji dostaw, wraz z czasem ich dostarczenia i przewidywanymi kosztami ${ }^{48}$. Ponadto firma może śledzić oferty innych potencjalnych dostawców, poszukując optymalnych rozwiązań ${ }^{49}$.

Innym rozwiązaniem (opartym także na ekstranecie) jest udostępnienie dostawcy informacji na temat własnych stanów magazynowych. Dotyczy to wybranych, stałych dostawców związanych z firmą długoterminowymi umowami. W takim przypadku dostawca może zalogować się na odpowiednią stronę internetową klienta, na której znajdują się aktu-

${ }^{46}$ Zasada 7W: właściwy towar, właściwemu klientowi, we właściwej ilości jakości, we właściwym miejscu i czasie oraz po właściwej cenie.

47 T. Maciejowski, Firma w Internecie, s. 251-252.

48 Jest to rozwiązanie typu ekstranet.

49 T. Maciejowski, Firma w Internecie, s. 252. 
alne informacje o stanie magazynu, i na tej podstawie sporządzić plan najbliższych dostaw. Zaawansowany system informatyczny może również wysyłać komunikat e-mail do dostawcy, sygnalizując optymalny moment realizacji dostawy. System, w którym dostawca zarządza zapasami producenta lub dystrybutora, odwracając $w$ ten sposób tradycyjne relacje handlowe, nosi nazwę VMI (Vendor Managed Inventory), inna nazwa to Supplier Managed Inventory - zarządzanie zapasami przez dostawcę.

Z doświadczeń na rynku wynika, że produktami najbardziej odpowiednimi do stosowania VMI sa te, których wykorzystanie jest łatwe w planowaniu, jak również produkty, dla których czynnikiem determinującym koszty są wydatki na procesy zaopatrzeniowe, a nie cena oraz takie, dla których producent wymaga długoterminowej umowy z dostawcą ${ }^{50}$.

Dla każdego rodzaju produktów można jednak dokonać analizy, czy może on być włączony w system VMI, czy też nie. Przy kontrolowanym i regularnym zużyciu danego produktu, którego specyfikacja jest zdefiniowana, częstotliwość zakupu również kontrolowana i regularna, a cena i dostawca są stali, można w pełni korzystać z VMI. Ten produkt spełnia bowiem wymogi, jakie niesie ze sobą stosowanie VMI. W przypadku zdefiniowanej specyfikacji produktu, przy jego nieregularnym, choć zestandaryzowanym zużyciu, również istnieje zgodność z wymogami VMI. Dodatkowymi warunkami sa: wysoka częstotliwość zakupu, stały dostawca oraz stała cena. Po spełnieniu tych warunków można wdrożyć zasady VMI dla analizowanego produktu ${ }^{51}$.

Systemy takie sa często zintegrowane z systemem obsługującym sprzedaż. Klient dokonujący zakupów w sieci widzi, ile sztuk danego produktu znajduje się na magazynie sprzedawcy, zaś po dokonaniu zakupu informacja o zmniejszonym stanie magazynowym trafia nie tylko do systemu sprzedawcy i na stronę internetowa, lecz także do jego dostawcy.

Systemem organizacji zaopatrzenia przyczyniającym się do usprawnienia procesu dokonywania zakupów w przedsiębiorstwie jest e-procurement. Umożliwia on efektywną i w pełni kontrolowaną współpracę firmy z dostawcami. Obejmuje cały proces zaopatrzeniowy - od zgłoszenia zapotrzebowania aż po weryfikację płatności. Obieg dokumen-

\footnotetext{
${ }^{50}$ www.logistyka.net.pl/index.php?option $=$ com_content\&task=view\&id $=4118 \& I t e m$ id $=40$ [z dn. 26.09.2011].

51 Tamże.
} 
tów jest zautomatyzowany i odbywa droga elektroniczna. System spełnia trzy podstawowe funkcje ${ }^{52}$ :

1) automatyzacja procesu zakupowego: e-procurement obejmuje cały proces zaopatrzeniowy $w$ całej organizacji i na wszystkich jej poziomach. Obieg dokumentów, wykorzystywanie e-podpisu, e-faktura odbywaja się droga elektroniczna,

2) kontrola zakupów: e-procurement umożliwia prowadzenie centralnej koordynacji planowania, budżetowania oraz monitorowania procesu zakupów. Pozwala to na uwolnienie departamentu zakupów od bieżących zadań i skoncentrowanie się na strategicznym wyborze dostawców oraz monitorowaniu współpracy,

3) standaryzacja asortymentu: wraz z e-procurement wprowadza się weryfikację kupowanego asortymentu i portfela dostawców. Poprawia to planowanie i współpracę $z$ dostawcami.

W rozwiązaniu typu e-procurement wyróżnia się trzy podstawowe elementy ${ }^{53}$ :

- system obsługi zaopatrzenia,

- system obsługi zamówień,

- platformę handlu B2B.

System umożliwia dostawcy m.in. stworzenie elektronicznego katalogu produktów i usług. Katalog taki może zawierać bardzo szczegółowe informacje o oferowanych towarach oraz różne cenniki, w zależności od tego, jakie ceny zostały wynegocjowane z danym kontrahentem.

Moduł obsługi zaopatrzenia wdrażany jest w firmie kupującej. W razie powstania zapotrzebowania na określony towar, pracownik firmy ma możliwość przeszukania elektronicznych katalogów zawierajacych szczegółowe informacje o produktach oferowanych przez poszczególnych dostawców, ich specyfikacje techniczne oraz wynegocjowane ceny. Po wybraniu konkretnego produktu użytkownik sprawdza jego dostępność i składa zapotrzebowanie. Tak sporządzone zapotrzebowanie jest najczęściej dodatkowo weryfikowane wewnątrz firmy. Sprawdza się np., czy towar, na który złożono zapotrzebowanie, nie jest zbyt drogi i czy mieści się w limicie wydatków wyznaczonym przez firmę. Gdy proces weryfikacji zostanie zakończony pomyślnie, osoba weryfikująca zatwierdza zapotrzebowanie, które jest następnie automatycznie przetwarzane na zamówienie lub zamówienia i wysyłane do danego dostawcy lub dostawców (jeśli zapotrzebowanie obejmowało produk-

${ }^{52}$ http://pl.wikipedia.org/wiki/E-procurement [z dn. 26.11.2012].

${ }^{53}$ A. Małachowski (red.), Wprowadzenie do i-handlu, Wyd. Akademii Ekonomicznej we Wrocławiu, Wrocław 2006, s. 44. 
ty/usługi pochodzące od kilku dostawców). Dzięki takiemu rozwiązaniu pracownik nie musi dzwonić do poszczególnych dostawców z pytaniem o dostępność produktów, nie składa tradycyjnych zamówień, zatem cały proces jest znacznie przyspieszony. Istotną zaletą rozwiązania e-procurement jest to, że system nie przeoczy, iż ulubiony dostawca podniósł "po cichu” ceny bąź ostatnim razem wysłał odbiorcy produkty wadliwe czy przeterminowane ${ }^{54}$.

Zamówienie w postaci e-dokumentu jest wysyłane do dostawcy za pośrednictwem platformy B2B. Dostawca może takie zamówienie przyjać, odrzucić lub zmienić status jego realizacji. Gdy zmówienie zostanie zaakceptowane, wysyłana jest przesyłka z zamówionym towarem. Po jej otrzymaniu firma kupująca rejestruje w systemie potwierdzenie odbioru oraz informacje o jakości towaru, a następnie akceptuje wystawiana przez dostawcę fakturę. Jeśli otrzymany towar jest wadliwy bądź nie jest zgodny ze specyfikacja określona w zamówieniu, uruchamiana jest procedura reklamacyjna (fakt otrzymania dostawy niespełniajacej warunków zamówienia jest odnotowywany w systemie e-procurement, a faktura wystawiona przez dostawcę pozostaje niezaakceptowana aż do chwili otrzymania właściwego towaru $)^{55}$.

\begin{tabular}{|cc|}
\hline OFERTA & standardowa wyspecjalizowana \\
\hline CENNIK & online \\
\hline MONITOROWECIE ZLECENIA & elektroniczne potwierdzenie \\
\hline JAKOSEC & przesylek \\
\hline RAPORTOWANIE & mierniki \\
\hline ZARZAZDZANIE MAGAZYNEM & odchyleń \\
\hline POTWIERDZENIE DOSTAWY & oline \\
ROZUICZENIE TRANSAKCII & elektronicznie \\
\hline
\end{tabular}

Rysunek 17. Wymogi stawiane operatorowi logistycznemu w handlu B2B

Źródło: opracowanie własne na podstawie: K. Rutkowski, Logistyka dystrybucji. Specyfika. Tendencje rozwojowe. Dobre praktyki, Wyd. SGH, Warszawa 2005, s. 95

${ }^{54}$ A. Małachowski (red.), Wprowadzenie do i-handlu, s. 45.
${ }_{55}$ Tamże. 
Logistyka stanowi podstawę, fundamentalna część zaplecza obsługującego transakcje elektroniczne rynku B2B, do jakich można zaliczyć zaopatrzenie e-sklepu. Rola operatora logistycznego polega na współdziałaniu z wieloma giełdami. Na niektórych rynkach może on uzyskać wyłączność partnerską, a z kolei na innych - musi być konkurentem w ramach aukcji ${ }^{56}$. Wymagania, jakie stawia się operatorowi logistycznemu, przedstawiono na rys. 17.

Warto w tym miejscu wspomnieć o e-fulfillment - usłudze zorientowanej na klienta. Terminologia e-commerce i e-fulfillment wymaga rozróżnienia. E-commerce to wszystkie transakcje związane z pozyskiwaniem środków finansowych, towarów i informacji, odbywające się przez Internet, poczynając od znalezienia produktu, negocjacji handlowych i wreszcie zakupu oraz dostaw. E-fulfillment obejmuje tylko i wyłącznie czynności realizacyjne, tzn. kalkulacje cenowe, ustalenie planu dostaw dla konkretnego klienta, znalezienie środka optymalnego transportu, składowisk itp., jak również przygotowanie i wymianę elektronicznej dokumentacji, system płatności, najczęściej za pomocą listu kredytowego, oraz przygotowanie asortymentu ${ }^{57}$.

Rysunki 18 i 19 przedstawiaja rolę operatora logistycznego w handlu elektronicznym oraz usługi e-fulfillment, czyli strategię zorientowaną na konkretnego klienta.

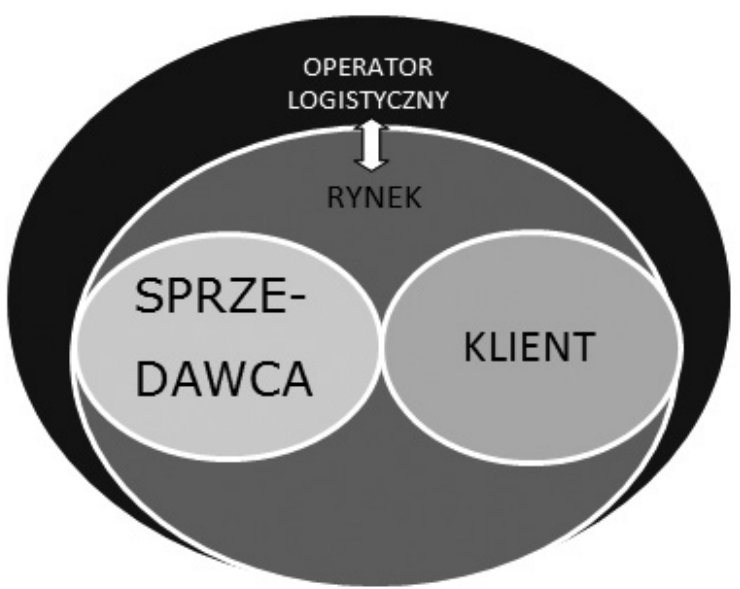

Rysunek 18. Rola operatora logistycznego w handlu elektronicznym

Źródło: opracowanie własne na podstawie: E. Januła, T. Truś, Gospodarka elektroniczna, Difin, Warszawa 2010, s. 96

\footnotetext{
56 Tamże.

${ }^{57}$ E. Januła, T. Truś, Gospodarka elektroniczna, Difin, Warszawa 2010, s. 96.
} 


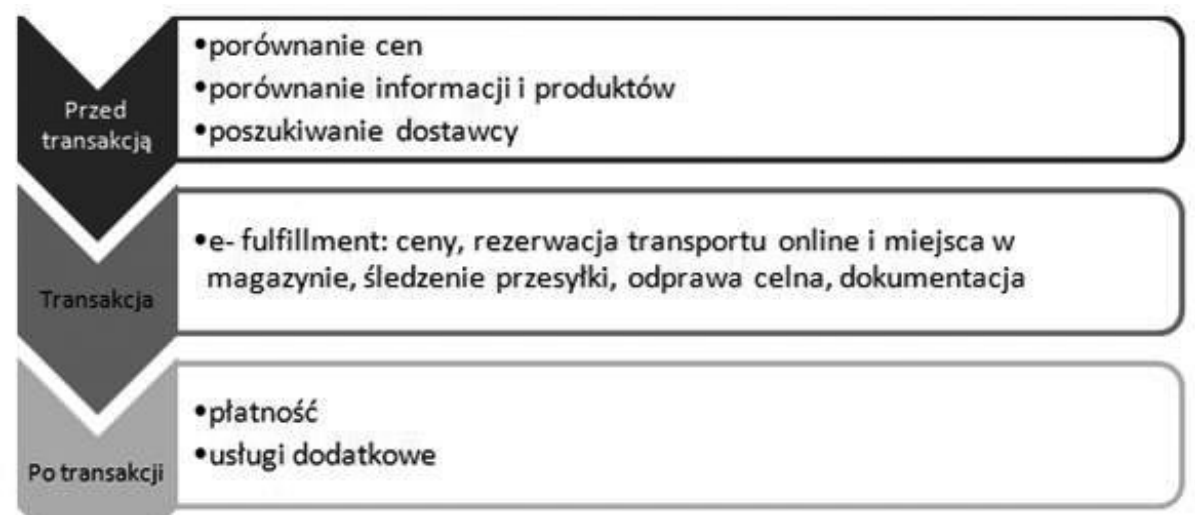

Rysunek 19. E-fulfillment

Źródło: jak do rys. 18, s. 97

Wszystkie usługi oferowane przez operatora logistycznego $\mathrm{w}$ ramach e-fulfillment musza być dostępne online, stanowi to bowiem podstawę zakresu usług oferowanych przez operatora. Gwarancją obecności na rynku sa czynniki, takie jak wysoki standard usług, a ich miernikami są: terminowość, dostawa dokładnie na czas, a także bez jakichkolwiek szkód.

W usługach e-fullfilment moga występować trzy fazy rozwiązań58:

- rozwiązanie bazowe - integracja usług transportowych i logistycznych offline,

- rozwiązanie zintegrowane - usługi transportowe i logistyczne (ustalanie cen, dostaw, zamawianie usług - online), wymagania to otwarte sieci informatyczne, które będą się mogły łączyć z sieciami innych podmiotów,

- rozwiązanie zaawansowane - wystawianie faktur online, zamówień online oraz elektroniczny obieg dokumentacji.

Operator logistyczny musi stale budować swoja pozycję w handlu elektronicznym poprzez zintegrowane usługi o wartości dodanej, oferowanie pakietów usługowych wraz z innymi usługodawcami, wystandaryzowany portfel usług dla klientów online, dostosowywanie procesów do szybkości i potrzeb globalnych oraz jednakowe standardy w całej organizacji.

Operator logistyczny w warunkach platformy B2B wykorzystuje elementy i narzędzia tradycyjnej gospodarki. Jednak Internet oraz za-

58 Tamże, s. 97. 
awansowane technologie łączności komórkowej tworzą zupełnie inne możliwości. Tego typu działalność jest widoczna w rozwoju rynku B2B. Funkcjonowanie rynku czy giełdy handlu elektronicznego, aby mogło się odbywać w sobie właściwy sposób, musi również zawierać w sobie usługę logistyczną ${ }^{59}$.

\subsubsection{Magazynowanie i gospodarka zapasami}

Każda firma handlowa musi przechowywać towary przeznaczone na sprzedaż. Poniżej przedstawione zostały rozwiązania dotyczące logistyki magazynowej sklepu internetowego (rys. 20).

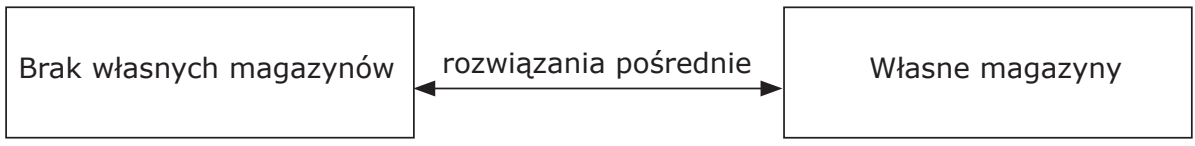

Rysunek 20. Sposoby rozwiązania dystrybucji i zaopatrzenia w sklepie elektronicznym

Źródło: T. Gajewska, Logistyczne aspekty wynikające z funkcjonowania handlu elektronicznego w ujęciu teorii i praktyki, "LogForum” 2009, t. 5, z. 3, nr 4, s. 4

Pierwsze rozwiązanie powiązane jest $z$ funkcjonowaniem firmy jako typowego pośrednika, którego zadaniem jest zdobycie zamówienia od klienta oraz realizacja tego zamówienia ${ }^{60}$. Odbywa się to dwuetapowo ${ }^{61}$ : 1) oferent składa zamówienie u producenta na wybrany przez odbiorcę produkt,

2) oferent wynajmuje firmę kurierską, której zadaniem jest dostarczenie zmówienia bezpośrednio do odbiorcy.

Takie rozwiązanie jest dogodne dla sprzedawcy, ponieważ nie jest on zmuszony do utrzymywania własnych magazynów, które musiałby regularnie kontrolować i zatrudniać wykwalifikowaną kadrę do ich obsługi.

Powyższy model ma zastosowanie w przypadku firm dopiero rozpoczynających działalność w Internecie, mających świadomość ponoszonego ryzyka i obawy odnośnie sprzedawanego asortymentu oraz przy-

${ }^{59}$ K. Rutkowski, Logistyka dystrybucji. Specyfika. Tendencje rozwojowe. Dobre praktyki, Wyd. SGH, Warszawa 2005, s. 94.

${ }^{60} \mathrm{~A}$. Małachowski (red.), Wprowadzenie do i-handlu, s. 31.

${ }^{61}$ Tamże, s. 32. 
szłego sukcesu i powodzenia działalności62. Omówione rozwiazanie ma szansę zaistnieć przy stosunkowo niewielkich obrotach firmy.

Podłoże prawidłowego działania zgodnie z tym modelem związane jest z koniecznością wynegocjowania bardzo korzystnych dla e-sklepu rabatów u producentów po to, aby nie podwyższać cen. W gestii firmy leży również zadbanie o organizację skutecznej komunikacji pomiędzy nia a partnerami, a także wybór niezawodnej i elastycznej firmy kurierskiej, bowiem w przypadku zwiększonej liczby zamówień wymagane będa zmiany, gdyż celem klienta jest otrzymanie towaru w jak najkrótszym czasie ${ }^{63}$.

Na drugie, skrajne rozwiązanie moga zdecydować się jedynie firmy dysponujące dużym kapitałem inwestycyjnym. To rozwiązanie wiaże się z przetrzymywaniem w magazynach całej oferty produktów. Na to moga sobie pozwolić jedynie producenci, którzy prosperuja na tradycyjnych rynkach ${ }^{64}$.

Posiadanie własnych magazynów łączy się przede wszystkim z wysokimi kosztami ich utrzymania, zatrudnieniem kadry nadzorującej zarówno zaopatrzenie, jak i przemieszczanie, sortowanie i wydawanie przechowywanych towarów. Stworzenie własnych magazynów jest również związane z koniecznością ciągłego nabywania produktów w celu zapełnienia powierzchni magazynowych. Dla przedsiębiorstwa działającego wyłącznie na rynku elektronicznym rozwiązanie to jest zarówno kosztowne, jak i ryzykowne ${ }^{65}$, gdyż przedsiębiorca, aby utrzymać płynność sprzedaży, musi posiadać nie tylko atrakcyjne towary, ale również te rzadziej kupowane. Na zamrożenie części kapitału w towarach rzadziej nabywanych moga więc sobie pozwolić firmy, które prowadza działalność internetowa jako dodatkowy kanał dystrybucji66.

Z omówionych wyżej rozwiązań najkorzystniejsze wydaje się rozwiązanie pośrednie, gdy firma dysponuje niewielkim zapasem produktów, które osiaggaja największy zbyt. Godne polecenia jest także magazynowanie niewielkiej ilości wyrobów, które maja pewny, stały poziom zbytu, choć niekoniecznie należą do produktów bardzo popularnych, w przypadku których czas oczekiwania na dostawę od producenta byłby bardzo długi ${ }^{67}$.

\footnotetext{
62 T. Gajewska, Logistyczne aspekty..., s. 4.

63 Tamże.

${ }^{64}$ A. Małachowski (red.), Wprowadzenie do i-handlu, s. 32.

65 B. Gregor, M. Stawiszyński, e-Commerce, Oficyna Wyd. Branta, Bydgoszcz 2002.

${ }^{66}$ A. Małachowski (red.), Wprowadzenie do i-handlu, s. 32.

67 T. Gajewska, Logistyczne aspekty..., s. 4.
} 
Rozwiązanie logistyczne polegajace na stworzeniu niewielkich własnych powierzchni magazynowych, służących do przechowywania produktów, których dostarczenie musi nastapić w bardzo krótkim czasie, najbardziej atrakcyjnych dla klientów, wydaje się najlepsze, gdyż sprzedawca może szybko zaspokoić potrzeby klienta, a jednocześnie nie ponosi dużych kosztów w związku z funkcjonowaniem magazynu ${ }^{68}$.

Współcześnie jednak firmy moga korzystać z centrów logistycznych, dających możliwość wynajęcia tylko niewielkiej części ich powierzchni, zaprojektowanych raczej $\mathrm{w}$ celu sprawnego przemieszczania produktów, a nie ich długotrwałego przetrzymywania. Najczęściej właścicielem takiego centrum jest operator logistyczny, który jednocześnie może zająć się całą logistyczną obsługą zamówień sklepu internetowego.

\subsubsection{Dystrybucja fizyczna i płatności}

Najważniejszym logistycznym aspektem funkcjonowania handlu elektronicznego jest problem dystrybucji towarów do odbiorcy.

W elektronicznych kanałach dystrybucji przepływy realizowane sa w dwóch wymiarach ${ }^{69}$ :

- elektronicznym, obejmujacym zarówno ogniwa wirtualne, jak i ich powiązania,

- fizycznym, obejmujacym tradycyjne systemy dystrybucji.

Sposób dystrybucji jest uzależniony od rodzaju sprzedawanych produktów, uczestników kanału i ich możliwości technologicznych oraz posiadanych zasobów. W przypadku produktów cyfrowych dostawa odbywa się przez Internet. Jeśli chodzi o produkty materialne, dostawa zawsze odbywa się fizycznie i stanowi najważniejszy etap realizacji zamówienia klientów. Dystrybucja fizyczna łączy się z wyborem odpowiedniej firmy kurierskiej i kwestią opłat za przesyłkę. Wspomniane koszty stanowia o łącznej cenie przesyłki i są kluczowym argumentem przy decydowaniu się na zakup towaru przez Internet ${ }^{70}$.

Optymalnym rozwiązaniem problemu prawidłowego przebiegu dystrybucji w handlu elektronicznym jest zaoferowanie klientowi kilku rozwiązań i pozostawienie w jego gestii możliwości wyboru firmy kurier-

${ }^{68}$ A. Małachowski (red.), Wprowadzenie do i-handlu, s. 32.

${ }^{69}$ W. Szymanowski, System dystrybucji internetowej jako nowe wyzwanie dla systemu dystrybucji w Polsce, "Prace Naukowe Politechniki Warszawskiej. Transport" 2010, z. 75 , s. 103.

70 Tamże. 
ZINTEGROWANYSYSTEM ZAMÓWIEŃ

- sprawdzenie dostęności towarów w magazynach

tasnychi obcych

- weryfikacja klienta

- obsługa płatności

- powiązania strony www i magazynu

- automatyczny e-mailing do klienta potwierdzając

realizacjęzamówienia
REALIZACJAZAMÓWIENIA
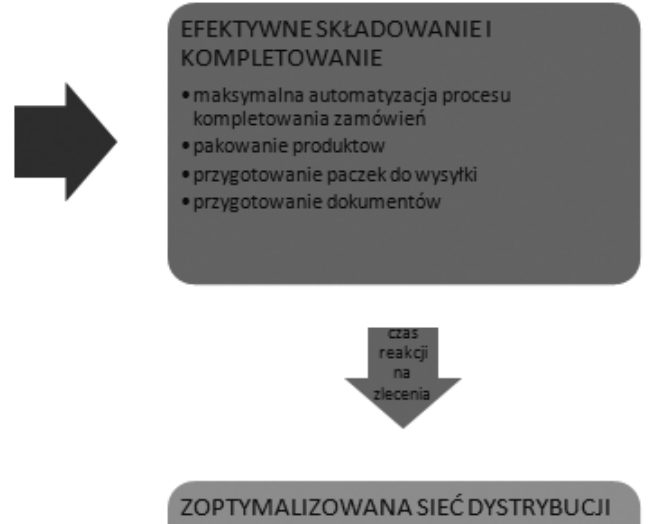

DOSTAWADO KLENTA

NATYCHMIASTOWA WYSYŁKA DO KLIENTA

-wysoka skuteczność dostaw

- gwarantowany czas dostawy

- zorientowanie na klienta

- dostawa wieczorna lub na określoną godzine

- możliwość śledzenia przeysłek online przez

konsumentów i przez firmy

Rysunek 21. Logistyka dystrybucji sklepu internetowego Źródło: jak do rys. 18, s. 102

skiej. Jednak tylko duże firmy, które dysponują sporym kapitałem, moga pozwolić sobie na wynegocjowanie korzystnych stawek i zmniejszyć opłaty za przesyłkę bądź całkowicie z nich zrezygnować. Strategicznym punktem mniejszych firm powinno być przynajmniej okazjonalne umożliwienie darmowej dostawy wybranych produktów. Darmowe wysyłanie towarów kupowanych przez Internet może być kluczową strategią w osiągnięciu zamierzonych celów. $Z$ danych pochodzących z Jupiter Media Metrix wynika, że w 2001 r. koszty wysyłki zniechęciły do zakupów elektronicznych aż $63 \%$ klientów $^{71}$. Działania takie wymagaja większych nakładów pracy i generuja wysokie koszty logistyczne, dlatego też sprzedaż towarów i usług, które można przenieść do cyberprzestrzeni, rośnie w większym tempie niż produktów materialnych.

W systemie logistyki dystrybucji w handlu elektronicznym B2C można wskazać różne modele fizycznej dystrybucji. Według K. Rutkowskiego, tworząc modele fizycznej dystrybucji, bierze się pod uwagę dwa czynniki²:

- kanał dystrybucji (sklep i centrum dystrybucji),

- sposób dostawy towaru (w obecności klienta i pod nieobecność klienta).

71 "Modern Marketing" 2001, nr 7/8, s. 12.

72 K. Rutkowski, Logistyka dystrybucji..., s. 232. 


\section{Model dostawy z fizycznego sklepu - klient oczekuje dostawy}

Wyróżnia się następujące cechy modelu ${ }^{73}$ :

- najniższy poziom inwestycji wstępnej,

- najwyższe koszty operacyjne ze względu na model dystrybucji oraz fakt, że dostawa w określonym czasie wymaga kosztownej optymalizacji obsługi transportowej,

- ograniczone możliwości generowania dodatkowej wartości dla klienta,

- ograniczona możliwość wprowadzenia usług dodatkowych, w tym również programów lojalnościowych, tylko do tego, co można zawrzeć na stronie internetowej.

Model dostawy z fizycznego sklepu oraz z centrum dystrybucji jest sposobem szybkiego wejścia na rynek, ale teoretycznie trudno osiągnąć $w$ ten sposób zysk. Wybór takiego modelu dostawy pozwolił brytyjskiemu detaliście Tesco zostać największym detalistą online na świecie. Dzięki takiemu rozwiązaniu dotarł on do prawie każdego gospodarstwa domowego przy relatywnie niskim koszcie. Inwestycja wstępna wyniosła ok. 56 mln USD.

\section{Model dostawy z fizycznego sklepu - klient nie oczekuje dostawy} Cechy modelu ${ }^{74}$ :

- potrzeba zainstalowania skrzynki odbiorczej (lub innego rozwiązania) na koszt sprzedawcy lub klienta,

- koszty wstępne zależą od pierwotnej liczby klientów i kształtują się na średnim poziomie,

- opcja użycia zwrotnej skrzynki na zakupy obniżyłaby poziom wstępnej inwestycji, jednak ograniczyłaby również możliwość rozszerzania pakietu usług i zwiększania lojalności klienta,

- koszty operacyjne będące wynikiem wyboru tego modelu dystrybucji (głównie kompletowanie zamówienia) sa ciągle wysokie, jednak całkowite koszty zmienne są już niższe dzięki mniej kosztownemu modelowi dostawy,

- z powodu większych możliwości planowania tras ten model jest także łatwiejszy do zoptymalizowania; efektywność systemu transportowego może być osiagnnięta nawet przy małej bazie klientów,

- istnieje możliwość połączenia tej opcji z modelem pierwszym oraz zaproponowania klientom wyboru wariantu dostawy,

- istnieje możliwość wprowadzania usług dodających wartości, np. don't run out Streamline'a (e-grocer automatycznie uzupełnia zapa-

\footnotetext{
${ }^{73}$ W. Szymanowski, System dystrybucji internetowej.., s. 104.
}

${ }^{74}$ K. Rutkowski, Logistyka dystrybucji..., s. 236. 
sy stale zużywanych przez klienta dóbr bez konieczności składania kolejnych zamówień, co pozwala osiągnać wysoki poziom lojalności klienta).

\section{Model dostawy z dedykowanego centrum dystrybucji - klient oczekuje dostawy}

Wyróżnia się następujące cechy modelu ${ }^{75}$ :

- wysokie koszty wstępne,

- niskie koszty kompletowania zamówienia,

- jest korzystniejszy ze względu na koszty operacyjne,

- rozmiar inwestycji wstępnej oraz wydajność kompletowania zamówień zależa od stopnia zautomatyzowania centrum dystrybucji,

- opłacalność przedsięwzięcia występuje przy wysokiej liczbie klientów,

- występuja silne wahania liczby zamówień w skali dnia, tygodnia i roku, w związku z tym trudno uzyskać tu równe wykorzystanie mocy przerobowej,

- konieczność utrzymywania dużych mocy przerobowych, gdyż centrum dystrybucji musi być w stanie obsłużyć klientów w okresach szczytu,

- ograniczona możliwość dodania innych usług i oferowania innych typów produktów.

Najbardziej znanym przykładem tego modelu był Webvan. Wraz ze wzrostem wolumenu sprzedaży firma chciała przejść na system zakupów bezpośrednio od producentów i importerów dóbr oraz bazować na dostawach od lokalnych producentów. Po wypełnieniu zamówienia na stronie www.webvan.com najbliższe klientowi centrum dystrybucji rozpoczynało kompletowanie zamówienia. Dzięki rozwiązaniom organizacyjno-informatycznym realizacja zamówienia była maksymalnie zautomatyzowana.

\section{Model dostawy z dedykowanego centrum dystrybucji - klient nie oczekuje dostawy}

Cechy modelu76:

- najwyższe koszty inwestycji,

- najniższe koszty operacyjne - transport i kompletowanie możliwe do zoptymalizowania,

\footnotetext{
75 Tamże.

76 Tamże, s. 241.
} 
- maksymalna wygoda i wartość dla klienta - świetna platforma do dodawania nowych usług i produktów jako dodatków do standardowych towarów spożywczych,

- e-grocer ma tu przewagę przetargowa wobec dostawców, gdyż z jednej strony odczuwa silne przywiązanie klientów (urządzenia do składowania produktów, oferowanie wygodnych usług dodatkowych), z drugiej - jest przy dużej ilościowo skali operacji poważnym graczem na rynku. Dodatkowo umacnia swoja pozycję poprzez możliwe do przeprowadzenia nadzorowanie, raportowanie zachowań konsumpcyjnych swoich klientów i oferowanie tych danych dostawcom,

- model jest trudny w zarządzaniu,

- wymaga dużej skali operacji, aby uzyskać opłacalność.

Tabela 25. Zestawienie porównawcze czterech modeli dostawy

\begin{tabular}{|c|c|c|c|c|}
\hline $\begin{array}{c}\text { Kategoria } \\
\text { porównywana }\end{array}$ & $\begin{array}{l}\text { Sklep - klient } \\
\text { oczekuje }\end{array}$ & $\begin{array}{l}\text { Centrum } \\
\text { - klient } \\
\text { oczekuje }\end{array}$ & $\begin{array}{l}\text { Sklep - klient } \\
\text { nie oczekuje }\end{array}$ & $\begin{array}{c}\text { Centrum } \\
\text { - klient } \\
\text { nie oczekuje }\end{array}$ \\
\hline $\begin{array}{l}\text { Niezbędna } \\
\text { inwestycja } \\
\text { wstępna }\end{array}$ & niska & wysoka & średnia & wysoka \\
\hline $\begin{array}{l}\text { Koszty komple- } \\
\text { towania zamó- } \\
\text { wienia }\end{array}$ & wysokie & niskie & wysokie & niskie \\
\hline $\begin{array}{l}\text { Koszty } \\
\text { transportu }\end{array}$ & wysokie & wysokie & niskie & niskie \\
\hline $\begin{array}{l}\text { Udogodnienie } \\
\text { dla klienta }\end{array}$ & niewielkie & niewielkie & duże & duże \\
\hline $\begin{array}{l}\text { Możliwość } \\
\text { szybkiego } \\
\text { rozwoju }\end{array}$ & nieduża & duża & średnia & problematyczna \\
\hline $\begin{array}{l}\text { Możliwość } \\
\text { usług dodaja- } \\
\text { cych wartości }\end{array}$ & ograniczona & ograniczona & średnia & bardzo duża \\
\hline $\begin{array}{l}\text { Lojalność } \\
\text { klienta }\end{array}$ & niska & niska & wysoka & wysoka \\
\hline $\begin{array}{l}\text { Możliwość do- } \\
\text { dania nowych } \\
\text { produktów }\end{array}$ & niska & przeciętna & przeciętna & wysoka \\
\hline $\begin{array}{l}\text { Przykłady } \\
\text { wdrożenia }\end{array}$ & Tesco, Y-halli & $\begin{array}{l}\text { Webvan, } \\
\text { Matomera }\end{array}$ & S-Kanava & Streamline \\
\hline
\end{tabular}

Źródło: K. Rutkowski, Logistyka dystrybucji. Specyfika. Tendencje rozwojowe. Dobre praktyki, Wyd. SGH, Warszawa 2005, s. 242. 
Najtańszym i najwygodniejszym z punktu widzenia logistyki rozwiązaniem dla e-handlu jest osobisty odbiór towaru przez klienta. Klient odbiera towar w siedzibie firmy bądź najbliższym mu tradycyjnym sklepie. Ponosi on wtedy tylko koszt związany z dostarczeniem zakupionego w sieci produktu do punktu jego odbioru.

Koszt dostawy towaru uzależniony jest od sposobu i czasu dostawy, a także od wartości zamówienia.

Oprócz systematycznej dostawy towaru w określonym czasie ważne jest także zapewnienie bezpieczeństwa dostarczanego towaru i komfort klienta. Pracownik firmy specjalistycznej dba, aby wszystkie przesyłki w zależności od ich zawartości i przeznaczenia dotarły do celu nieuszkodzone. Zapewnia również pomoc przy rozładunku towaru.

Podstawowym zadaniem firm spedycyjnych jest organizowanie przewozu przesyłek i załatwianie formalności z tym związanych. Inaczej rzecz ujmujac, spedytor pośredniczy w wymianie towarowej pomiędzy dwoma kontrahentami ${ }^{77}$.

Spełniając funkcję organizatora procesów przemieszczania, firma spedycyjna ma zasadniczy wpływ na usprawnianie funkcjonowania całego systemu transportowego, tak więc mówiąc o procesie transportowym, wyróżnić należy78:

- proces przewozowy, na który składa się: załadunek, przewóz, przeładunek, przewóz i wyładunek,

- spedycję, która poprzedza i kończy proces przewozowy, zajmując się przygotowaniem ładunku do transportu (m.in. kompletowaniem), magazynowaniem przejściowym, organizacja transportu i czynnościami zdawczo-odbiorczymi.

Obecnie firmy spedycyjno-transportowe dążą do integracji procesu transportowego, poprzez integrację sprzętu, metod, procedur, danych i sposobów organizacji, w celu zaoferowania klientom kompleksowej usługi logistycznej. Operator logistyczny zajmujący się organizacja, zarządzaniem i realizacja kompleksowych procesów transportowych, podejmuje istotne decyzje związane z fizyczna dystrybucją towarów ${ }^{79}$.

Wysoki standard usług może zaoferować tylko taki podmiot, który dysponuje własna siecia oddziałów w kraju i za granica, odpowiednim potencjałem magazynowym, przeładunkowym i zapleczem technicznym, niezawodna łącznością i sprawnymi metodami kontroli przebie-

77 M. Kiba, Rola EDI w usługach spedycyjno-transportowych, [w:] A. Tubielewicz (red.), Electronic commerce..., s. 62.

${ }^{78}$ Tamże.

79 Tamże. 
gu procesów transportowych, a przede wszystkim doświadczoną i fachowa kadra.

Coraz częściej firmy spedycyjno-transportowe łączą się w różnego rodzaju spółki lub kooperacje w celu stworzenia wspólnego centrum logistycznego. Dzięki takim rozwiązaniom przedsiębiorstwa są w stanie świadczyć szerszy wachlarz usług logistycznych oraz stają się bardziej elastyczne w odniesieniu do potrzeb klienta, jednocześnie minimalizując koszty.

W najprostszy sposób Internet można wykorzystać w transporcie do śledzenia przesyłek poprzez stronę WWW spedytora. Bardziej zaawansowane rozwiązanie polega na kompleksowym wspomaganiu spedycji w Internecie - w takim przypadku konieczne jest stworzenie silniejszych więzi między spedytorem a zleceniodawcą (nie ma ekonomicznego sensu uruchamianie narzędzi internetowych do jednorazowej usługi) ${ }^{80}$.

Najpopularniejszą usługa internetową związaną z fizycznym transportem jest monitoring transportu online. Służa do tego systemy automatycznej lokalizacji (webtracker). Klient, nadając przesyłkę kurierską w tradycyjny sposób, otrzymuje potwierdzenie wraz z numerem tzw. listu przewozowego lub numerem przesyłki. Na stronie internetowej kuriera wystarczy wpisać ów numer - wówczas wyświetlą się informacje na temat przesyłki, m.in. miejsce przeznaczenia, przewidywana data odbioru oraz informacje o statusie przesyłki (czy jest w drodze, w jakim centrum dystrybucji się znajduje, czy została dostarczona itd. $)^{81}$.

Sprzedaż usług logistycznych gwałtownie wzrasta pod koniec roku, tj. w listopadzie i grudniu, ponieważ jest to okres przedświąteczny, charakteryzujący się największym obciążeniem sklepów internetowych. W tym czasie liczba paczek krążących pomiędzy adresatami i nadawcami jest dwa razy większa niż ma to miejsce w innych miesiącach. Ponieważ liczba osób obsługi pozostaje stała, proporcje zostaja zaburzone na niekorzyść klientów. Pojawiaja się problemy z obsługa tylu zleceń, a także z logistycznym dostarczeniem wszystkich przesyłek na czas. Moga one prowadzić do opóźnień w dostawach i obniżenia jakości usług ${ }^{82}$.

Część sklepów stara się znaleźć rozwiązanie, zwiększając liczbę personelu realizującego zamówienia. W dalszym ciągu jednak główną przeszkodą pozostaje logistyka. W przypadku największych firm

\footnotetext{
${ }^{80}$ T. Maciejowski, Firma w Internecie, s. 256.

81 Tamże.

${ }^{82}$ T. Gajewska, Logistyczne aspekty..., s. 3.
} 
ogromna liczba otrzymywanych zamówień zmusza je do skorzystania $z$ usług zewnętrznych firm dystrybucyjnych. W odniesieniu do firm specjalistycznych, mogących zainwestować we własną logistykę, problem może mieć łagodniejsze skutki. Możliwość kupna dodatkowych samochodów dostawczych znacznie polepsza sytuację firmy, jednak generuje wysokie koszty. Wskazane wyżej rozwiązanie pozwala na prawidłowe funkcjonowanie systemu łańcucha dostaw bez konieczności korzystania z usług poczty lub firm kurierskich ${ }^{83}$.

Klient oprócz wyboru formy dostawy może także wybrać sposób zapłaty za swoje zakupy. Płatności za towar dokonuje się w sposób tradycyjny lub droga elektroniczna. Wśród tradycyjnych można wyróżnić84:

- przelew bankowy,

- przekaz na konto (przekaz pieniężny),

- zaliczenie pocztowe (płatność przy odbiorze),

- zapłatę czekiem ${ }^{85}$.

Natomiast elektroniczne formy płatności to ${ }^{86}$ :

- czek elektroniczny,

- zapłata za pomoca karty płatniczej (lub kredytowej),

- zapłata za pomoca elektronicznych pieniędzy.

Ponadto wraz z rozwojem usług internetowych wprowadzono nowe formy płatności, np. przez SMS ${ }^{87}$ czy za pośrednictwem e-maila88.

W Polsce najbardziej popularnym systemem opłat za towar zamówiony za pośrednictwem Internetu jest pobranie pocztowe przy odbiorze towaru przez klienta. Szacuje się, iż w ten sposób opłaca się $67 \%$ wszystkich transakcji zawieranych $w$ Internecie ${ }^{89}$, a oferuje je prawie 90\% sklepów internetowych.

Za popularnością płatności za pobraniem przemawia przede wszystkim powszechna znajomość tego systemu wśród klientów i łatwość jego obsługi (wymagana jest jedynie zapłata i podpis) oraz dostępność -

83 Tamże.

${ }^{84}$ R. Kański, Podstawy i rozwój e-biznesu, Wyższa Szkoła Handlowa we Wrocławiu, I-Bis, Wrocław 2005, s. 60.

${ }^{85}$ Obecnie płatności czekiem nie są już stosowane.

86 Tamże.

87 Płatności SMS dotyczą często drobnych usług stricte internetowych, np. opłaty za wejście do płatnej części serwisu lub możliwość ściagnięcia pliku.

${ }^{88}$ W Polsce płatności e-mail umożliwia serwis PayPal i wzorowany na nim serwis PayU. Płatności e-mail polegają na wysłaniu żądania zapłaty, np. w postaci faktury elektronicznej, a klient po otrzymaniu takiego specjalnego e-maila dokonuje bezpiecznej płatności w serwisie.

${ }^{89}$ A. Małachowski (red.), Wprowadzenie do i-handlu, s. 63. 
z rozwiązania może skorzystać praktycznie każdy klient w Polsce. Argumentem "za" jest także bezpieczeństwo, ponieważ zarówno dane finansowe, jak i pieniądze nie sa przekazywane poza kontrola klienta, a opłata następuje przy fizycznym odbiorze produktu ${ }^{90}$. Dla sklepu to rozwiazanie jest najprostsze i nie wymaga nakładów finansowych oraz pracochłonności przy jego wdrożeniu.

Opłaty pobraniowe nie są także pozbawione wad. Przede wszystkim wymagaja posiadania przez klienta gotówki, co przy większych kwotach może sprawić problemy. Po drugie, należy się liczyć z wyższymi kosztami związanymi z opłata za pobranie ze strony firm kurierskich czy poczty ${ }^{91}$. Ryzyko podejmuje także sklep internetowy - kiedy klient nie odbierze przesyłki, sklep ponosi koszty jej zwrotu.

Chociaż większość serwisów umożliwia płacenie kartami kredytowymi, użytkownicy są raczej niechętni tej formie zapłaty, nie ufając mechanizmom bezpieczeństwa92.

Niektóre sklepy, aby zachęcić klientów do zakupów, podpisały umowy z konkretnymi bankami, które umożliwiaja płatności z uwzględnieniem swoich rozwiązań bezpieczeństwa ${ }^{93}$.

Zaletami kart płatniczych są: szybkie, bezgotówkowe rozliczenie transakcji, coraz większa powszechność w Polsce i na świecie, bezpieczeństwo stosowania (w przypadku bezpośredniego przekazywania danych do centrum autoryzacji sklep nie ma wglądu w dane karty, więc nie ma możliwości włamania).

Wraz z rozwojem bankowości elektronicznej i usług typu e-konto, powszechne stały się płatności „z góry” przelewem bankowym. Towar jest wysyłany zazwyczaj zaraz po zaksięgowaniu wpłaty na koncie sprzedającego, jednak klient podejmuje ryzyko, bowiem nie ma pewności, czy towar zostanie wysłany, a pieniądze nie przepadna.

Najpopularniejszy serwis aukcyjny w Polsce, Allegro.pl, wprowadził własny system e-płatności o nazwie „płacę z Allegro”. Po dokonaniu zakupów w serwisie Allegro klient wybiera sposób dostawy towaru. Koszty wybranej formy przesyłki sa doliczane do ceny towaru i system automatycznie przekierowuje klienta na stronę wybranego przez niego banku, w którym posiada on konto, lub na serwis obsługujący płatności kartą kredytową. Jednocześnie do sprzedającego i kupującego wy-

\footnotetext{
90 Tamże.

${ }_{91}$ A. Małachowski (red.), Wprowadzenie do i-handlu, s. 63.

92 R. Barcik, Logistyka dystrybucji, Wyd. ATH, Bielsko-Biała 2005, s. 327.

93 Tamże.
} 
syłane sa maile informujace o dokonaniu transakcji, wyborze sposobu zapłaty, dokonaniu płatności i otrzymaniu zapłaty przez sprzedającego.

Nową metoda płatności, dostępną tylko w świecie wirtualnym, jest płatność elektronicznymi pieniędzmi.

Pieniądz elektroniczny to wartość pieniężna stanowiąca elektroniczny odpowiednik znaków pieniężnych, która spełnia łącznie następujace warunki ${ }^{94}$ :

- jest przechowywana na elektronicznych nośnikach informacji,

- jest wydawana do dyspozycji na podstawie umowy, w zamian za środki pieniężne o nominalnej wartości nie mniejszej niż ta wartość,

- jest przyjmowana jako środek płatniczy przez przedsiębiorców innych niż wydajacy ja do dyspozycji,

- na żądanie jest wymieniana przez wydawcę na środki pieniężne,

- jest wyrażona w jednostkach pieniężnych.

Najprościej mechanizm działania pieniędzy elektronicznych można porównać do "elektronicznego portfela", który w każdej chwili można załadować pieniędzmi. Rozwiązanie to jest w pełni bezpieczne, nie ma obawy, że ktoś dokona płatności na nasz koszt, ponieważ płacić można tylko wtedy, gdy w portmonetce znajduja się pieniądze.

\subsubsection{Logistyka zwrotna}

Logistyka zwrotna stanowi stosunkowo nowy obszar badawczy, zarówno w warstwie teoretycznej, jak i empirycznej. W literaturze anglojęzycznej można spotkać takie pojęcia, jak dystrybucja odwrotna (reverse distribution), logistyka zwrotów (return logistics), odwrócona logistyka (reversed logistics) czy logistyka działająca wstecz (retro logistics), które $w$ istocie odnoszą się do tych samych zagadnień.

Logistyka zwrotna w sposób zasadniczy różni się od takich dziedzin, jak zarządzanie odpadami, które odnosi się głównie do skutecznego i efektywnego zbierania oraz przetwarzania odpadów. W zarzadzaniu odpadami przyjmuje się, że pojęcie odpadów określa produkty, dla których nie istnieje nowe zastosowanie. Wypływa stąd wniosek, iż problemy z uściśleniem koncepcji logistyki zwrotnej oraz jej odgraniczeniem od innych, pokrewnych dziedzin nauki, sprowadzaja się do rozumienia pojęcia "odpady" wraz ze wszystkimi wynikającymi z definicji konsekwencjami. Logistyka zwrotna dotyczy takich strumieni przepły-

${ }^{94}$ R. Kański, Podstawy i rozwój e-biznesu, s. 61. 
wów, w których istnieje możliwość odtworzenia wartości z wycofywanych produktów oraz sytuacji, gdy wyjście stanowi zasilenie dla nowego łańcucha dostaw ${ }^{95}$.

Produktami logistyki zwrotnej sa:

- produkty uszkodzone,

- produkty błędnie dostarczone,

- produkty zużyte,

- produkty zbędne,

- opakowania,

- odpady.

Przy projektowaniu kompletnego systemu logistyki dla e-handlu trzeba uwzględnić przepływy produktów w obie strony, czyli ują́ logistykę zwrotną. Kanały dystrybucji elektronicznej musza być dostosowane do obsługi zwrotów i reklamacji od pojedynczych klientów. Powinny uwzględniać możliwość zwrotu produktu z powodu jego wad, uszkodzeń lub niespełnienia oczekiwań oraz utworzenie systemu obsługi, który wpływa na poziom obsługi klienta i tym samym jego zadowolenie.

W handlu elektronicznym można wyróżnić następujące obszary logistyki zwrotnej:

- zwroty produktów nieuszkodzonych,

- reklamacje i gwarancje,

- utylizacja zużytego sprzętu,

- gospodarka opakowaniami.

Sprzedawcy internetowi, aby zachęcić klientów do robienia zakupów w sieci i zapewnić wysoki poziom obsługi, wprowadzili liberalna politykę zwrotów, gwarantując możliwość oddania zakupionego towaru bez względu na powód rezygnacji z zakupionego produktu.

Do najczęstszych przyczyn zwracania towarów kupionych w Internecie należą: wady produktów i ich uszkodzenia, niezgodność co do ilości lub rodzaju otrzymanych produktów z zamówieniem, zwroty niesprawnych urządzeń na gwarancji, niespełnienie oczekiwań klienta ${ }^{96}$.

Odsetek zwrotów zakupów online różni się w zależności od branży i rodzaju dóbr, ale z reguły jest od 50 do $100 \%$ wyższy w porównaniu z tradycyjnym handlem. W przypadku zakupu odzieży obserwuje się rosnąca tendencję do stosowania tego typu praktyk. Klienci zamawiaja określona rzecz w kilku rozmiarach, a po przymierzeniu zwracają niepasujace ${ }^{97}$.

\footnotetext{
${ }^{95}$ A. Sadowski, Zarys rozwoju logistyki zwrotnej, "Logistyka” 2009, nr 5.

${ }^{96}$ K. Rutkowski, Logistyka dystrybucji.., s. 229.

97 Tamże.
} 
W przypadku zakupu towaru przez Internet, na podstawie ustawy z dnia 2 marca 2000 r. o ochronie niektórych praw konsumentów oraz o odpowiedzialności za szkodę wyrządzona przez produkt niebezpieczny, mamy prawo do zwrotu towaru bez podania jakiejkolwiek przyczyny w okresie do 10 dni od jego otrzymania, a w przypadku, kiedy sprzedawca nie poinformował nas o tym prawie, ten czas wydłuża się nawet do 3 miesięcy ${ }^{98}$.

Należy jednak pamiętać, iż w przypadku zwrotu towaru to klient ponosi koszty jego odesłania, a zwrotowi podlega tylko kwota równa wartości towaru, czyli klient jest stratny o dwukrotne koszty przesyłki.

W przypadku uszkodzeń wynikających z niewłaściwego transportu towaru i widocznego uszkodzenia przesyłki należy otworzyć paczkę w obecności listonosza (kuriera) i poprosić o odpowiednią adnotację o uszkodzeniu opakowania (nawet, gdy towar nie wydaje się uszkodzony) ${ }^{99}$.

W przypadku ujawnienia się wady, możemy wedle swego uznania skorzystać z gwarancji producenta (o ile taka była udzielona i nie minał okres gwarancyjny) lub instytucji niezgodności towaru z umową na podstawie ustawy z dnia 27 lipca 2002 r. o szczególnych warunkach sprzedaży konsumenckiej oraz o zmianie Kodeksu cywilnego ${ }^{100}$.

Menedżerowie e-sklepów nie moga ignorować tego problemu, a politykę i system zwrotów powinni opracować w momencie tworzenia strategii dystrybucji. Dla e-sprzedaży obsługa zwrotów stanowi dużo większy problem niż dla tradycyjnego biznesu, ponieważ trzeba określić i zorganizować efektywne procedury odbioru pojedynczych dóbr od konsumentów, a trudno jest określić zapotrzebowanie na te usługi pod względem ilości, jakości oddawanych dóbr, a co za tym idzie, nie można jednoznacznie zaplanować obciążenia tras powrotnych dla towarów i zdecydować, czy wykonywać te czynności we własnym zakresie czy je outsourcingować ${ }^{101}$.

W procesie obsługi zwrotów ważnym etapem jest określenie przyczyny zwrotu i na tej podstawie określenie drogi powrotnej towarów. Taki zabieg pozwala na minimalizację kosztów obsługi logistycznej

98 Ustawa z dn. 2 marca 2000 r. o ochronie niektórych praw konsumentów oraz o odpowiedzialności za szkodę wyrządzoną przez produkt niebezpieczny, Dz.U. z 2000 r., nr 22, poz. 271 z późn. zm.

${ }^{99}$ R. Barcik, Logistyka dystrybucji, s. 330.

100 Ustawa z dn. 27 lipca 2002 r. o szczególnych warunkach sprzedaży konsumenckiej oraz o zmianie Kodeksu cywilnego, Dz.U. z 2002 r., nr 141, poz. 1176 z późn. zm.

${ }^{101}$ K. Rutkowski, Logistyka dystrybucji..., s. 229. 
zwrotów. Zamiast wysyłać od razu wszystkie produkty w górę łańcucha dostaw, należy w punkcie przyjmowania zwrotów sprawdzić produkt pod względem jakości oraz ustalić rodzaj usterki i na tej podstawie podejmować dalsze decyzje co do produktu. Produkty w dobrym stanie, nieuszkodzone, moga wrócić do sprzedaży, zaś uszkodzone należy naprawić i zwrócić klientowi lub wprowadzić do wtórnej sprzedaży. Produkty, których nie można naprawić lub ponownie sprzedać, trzeba oddać na złom lub do recyklingu.

Osobnym problemem jest gospodarka opakowaniami. Przepisy z zakresu gospodarki opakowaniami i odpadami opakowaniowymi, które stanowią transpozycję postanowień unijnej dyrektywy "opakowaniowej", obowiazuja w Polsce od ponad 7 lat. Już w 2007 r. Polska powinna osiagnąć poziom odzysku $50 \%$ i recyklingu $25 \%$ łącznej masy opakowań wprowadzanych na rynek krajowy wraz z wyrobami. Oznacza to, że połowa opakowań wykorzystywanych w Polsce do pakowania produktów, po utracie swojej funkcjonalności nie miała prawa trafić na składowiska. Wymogi w tym zakresie stale rosna, do 2014 r. Polska jest zobowiązana osiągnąc odzysk opakowań na poziomie $60 \%$, zaś recykling na poziomie minimum $55 \%$.

Bezpośrednią odpowiedzialność za realizację tych zobowiązań ponoszą przedsiębiorcy wprowadzający na rynek produkty w opakowaniach. W myśl zasady "zanieczyszczający płaci" muszą oni zadbać o swój produkt w całym cyklu jego życia. Co za tym idzie, powinni również zapewnić wymagany prawem poziom odzysku i recyklingu odpadów, które powstana z opakowań ich produktów.

Wspomniane wyżej zobowiązania zostały w Polsce wprowadzone na mocy dwóch ustaw, będących implementacja postanowień dyrektywy Parlamentu i Rady Europejskiej nr 94/62/WE z dnia 20 grudnia 1994 r. w sprawie opakowań i odpadów opakowaniowych:

- ustawy z dnia 11 maja 2001 r. o obowiązkach przedsiębiorców w zakresie gospodarowania niektórymi odpadami oraz o opłacie produktowej i opłacie depozytowej (tekst jedn.: Dz.U. z 2007 r., nr 90, poz. 607 z późn. zm.),

- ustawy z dnia 11 maja 2001 r. o opakowaniach i odpadach opakowaniowych (Dz.U. z 2001 r., nr 63, poz. 638 z późn. zm.).

Obie ustawy weszły w życie 1 stycznia 2002 r. Swoim zakresem dotyczącym obowiązku odzysku i recyklingu opakowań objęły następujace grupy przedsiębiorców:

- wytwórców produktów w opakowaniach,

- importerów oraz firmy dokonujace wewnatrzwspólnotowego nabycia towaru (WNT z wykluczeniem importu lub WNT w celach eksportu, albo wewnątrzwspólnotowej dostawy towarów - WDT), 
- przedsiębiorców prowadzących jednostkę handlu detalicznego o powierzchni handlowej powyżej $500 \mathrm{~m}^{2}$ sprzedających produkty tam pakowane,

- przedsiębiorców prowadzących więcej niż jedna jednostkę handlu detalicznego o łącznej powierzchni handlowej powyżej $5000 \mathrm{~m}^{2}$, sprzedających produkty tam pakowane,

- przedsiębiorców, którzy pakuja produkty wytworzone przez innego przedsiębiorcę i wprowadzaja je na rynek krajowy,

- przedsiębiorców niebędących wytwórcami produktu, którzy zlecili wytworzenie tego produktu oraz których oznaczenie zostało umieszczone na produkcie lub opakowaniu.

Firmy te sa zobowiązane do zapewnienia określonego prawem poziomu odzysku i recyklingu odpadów powstałych z opakowań produktów wprowadzanych na polski rynek.

Opakowania, z których przedsiębiorcy powinni się rozliczać, obejmuja te wykonane z tworzyw sztucznych, aluminium, stali, papieru i tektury, szkła gospodarczego oraz drewna. Przepisom ustawy podlegają także opakowania wielomateriałowe, obciążające obowiązkiem odzysku i recyklingu w zakresie przeważającej grupy materiałowej (np. kartony do pakowania płynnej żywności, w ok. 70\% składające się z papieru, rozliczane będa jako opakowania z papieru i tektury).

Rozliczenie wprowadzanych na rynek opakowań następuje na koniec roku kalendarzowego. W przypadku nieosiągnięcia określonych prawem poziomów odzysku i recyklingu, przedsiębiorcy sa zobowiązani do uiszczenia do urzędu marszałkowskiego opłaty produktowej. Jest to najbardziej kosztowny sposób realizacji obowiazków. Opłata ta ma charakter sankcyjny, mający zmusić przedsiębiorców do poszukiwania innych, bardziej ekologicznych sposobów realizacji ustawowych obowiązków.

W celu uniknięcia wysokich kosztów, przedsiębiorcy moga zaangażować się w odzysk i recykling. Mają dwie możliwości: samodzielną realizację obowiązków lub przekazanie ich organizacji odzysku.

Decydując się na tę pierwszą opcję, należy dokonać fizycznego przetworzenia odpadów lub zorganizować sieć selektywnego ich zbierania w celu zapewnienia recyklingu. Decydując się na samodzielną realizację ustawowych obowiązków, nie można zapominać o szczegółowej weryfikacji firm recyklingowych pod kątem wymogów prawnych. Dokumenty potwierdzające odzysk i recykling (DPO i DPR) wystawione przez firmy nieposiadające do tego stosownych uprawnień będa w świetle prawa nieważne. W ten sposób realizacja obowiązku odzysku i recyklingu będzie nieskuteczna, co spowoduje konieczność uiszczenia opłaty produktowej do urzędu marszałkowskiego. 
Prostym sposobem uniknięcia tych problemów jest przekazanie ciażących na przedsiębiorcach obowiązków organizacji odzysku. Firma ta na mocy ustawy jest podmiotem ściśle wyspecjalizowanym w zakresie realizacji obowiązku odzysku i recyklingu. Organizacja odzysku musi zadbać o monitorowanie działania firm recyklingowych, bo to ona ponosi odpowiedzialność za wszelkie nieprawidłowości w tym zakresie. Nawiązując współpracę z organizacją odzysku, przedsiębiorca unika zarówno ryzyka związanego z niewłaściwym gospodarowaniem odpadami, jak i obowiązku sprawozdawczego, który zostaje przeniesiony na organizację odzysku. Rozliczenie za pośrednictwem organizacji odzysku jest w chwili obecnej najpopularniejszym sposobem wywiązywania się z postanowień ustawy o opłacie produktowej.

\subsection{Aspekty logistyczne polskiego rynku e-commerce w świetle wyników badań własnych}

\subsubsection{Metodyka badań}

Jak już wcześniej wspomniano, bez dobrze zorganizowanej logistyki sklep internetowy nie mógłby prawidłowo funkcjonować. Kluczową kwestią e-zakupów jest szybkość dostarczenia zakupionego towaru do klienta. Maja na to wpływ dwa kluczowe czynniki:

- sposób płatności - w przypadku płatności z góry towar jest wysyłany dopiero po zaksięgowaniu wpłaty na koncie sklepu, co może powodować opóźnienie w wysyłce o czas potrzebny na operacje bankowe; w przypadku płatności za pobraniem wysyłka następuje od razu po złożeniu zamówienia,

- wybór firmy kurierskiej - usługi prywatnych firm kurierskich są zazwyczaj "szybsze” od usług pocztowych.

W celu zbadania logistyki polskich sklepów internetowych, na przełomie stycznia i lutego 2012 r. rozesłano do sklepów internetowych prawie 1200 zaproszeń do udziału w badaniu.

Sklepy miały dwie możliwości uczestniczenia w badaniu - poprzez wypełnienie ankiety umieszczonej na portalu moje-ankiety.pl lub odesłanie ankiety załączonej w zaproszeniu. Ankieta składała się z 25 pytań jedno- i wielokrotnego wyboru, które można podzielić na kilka kategorii. Pytania dotyczyły:

- branży, w jakiej sklep działa, liczby zatrudnionych pracowników i czasu istnienia sklepu, 
- zaopatrzenia sklepu i jego gospodarki magazynowej,

- płatności, jakie oferuje sklep,

- form dystrybucji oferty w Internecie oraz sposobu dostarczania towaru do klienta,

- logistycznej obsługi klienta.

W badaniu wzięło udział 110 sklepów - 103 z nich wypełniły ankietę online, 7 odesłało mailem. Taka liczba bioracych udział $w$ badaniu stanowi nieco ponad $1,1 \%$ populacji, co pozwala uznać wyniki badania za wiarygodne.

\subsubsection{Analiza wyników badań własnych}

\section{Struktura polskich e-sklepów}

Pytanie pierwsze dotyczyło branży, w jakiej działa sklep. Ankietowani mieli do wyboru jedna z 20 branż, a także możliwość wpisania własnej odpowiedzi. Tak duże rozdrobnienie sklepów pozwala na dokładniejszą ich analizę i scharakteryzowanie specyficznych cech (wykres 2).

Najpopularniejszą okazała się branża "dom i ogród”, której produkty oferuje co piąty sklep. Drugie miejsce zajęły sklepy sprzedajace odzież i obuwie, na trzecim znalazły się ex aequo: sklepy z branży komputery i Internet oraz zajmujące się sprzedażą produktów dla dzieci. Do najmniej popularnych branż należą: filmy, fotografia i gry, które wskazał niecały jeden procent sklepów, a także (z wynikiem prawie $2 \%$ ) branże: delikatesy, motoryzacja, muzyka i instrumenty, przemysł, telefony i akcesoria, usługi oraz zwierzęta. Delikatesy to sklepy oferujące sprzedaż online produktów spożywczych. Takie sklepy nie działaja w zasięgu całego kraju, lecz jedynie lokalnie - najczęściej w największych polskich miastach i w ramach tych miast oferuja dostawę towaru do domu klienta.

W kategorii inne, którą wskazało ponad 4,5\% sklepów, znalazły się branże: ekologia, elektronika użytkowa, rolnictwo, przedmioty ręcznie wykonane oraz elektronarzędzia. Każda z wymienionych branż dotyczy 0,91\% ankietowanych. Nikt nie wskazał branży nieruchomości.

Jak przedstawiono na wykresie 3, prawie $43 \%$ polskich sklepów to mikroprzedsiębiorstwa - sklepy jednoosobowe, z których prawie 20\% to te działające krócej niż rok, a 40,43\% funkcjonuje od roku do dwóch lat. Świadczy to o tym, że przedsiębiorcy dostrzegają ogromny potencjał prowadzenia biznesu w sieci i nie boją się podjać związanego z tym ryzyka. Cztery na dziesięć sklepów obsługiwanych jest przez co naj- 
mniej dwie osoby. Co dziesiąty sklep zatrudnia ponad 30 pracowników, z czego $8 \%$ to duże sklepy obsługiwane przez ponad 50 osób. Charakterystyczne jest, że 7 na 9 największych sklepów istnieje od ponad 6 lat, co zapewne przyczyniło się do ich rozwoju.

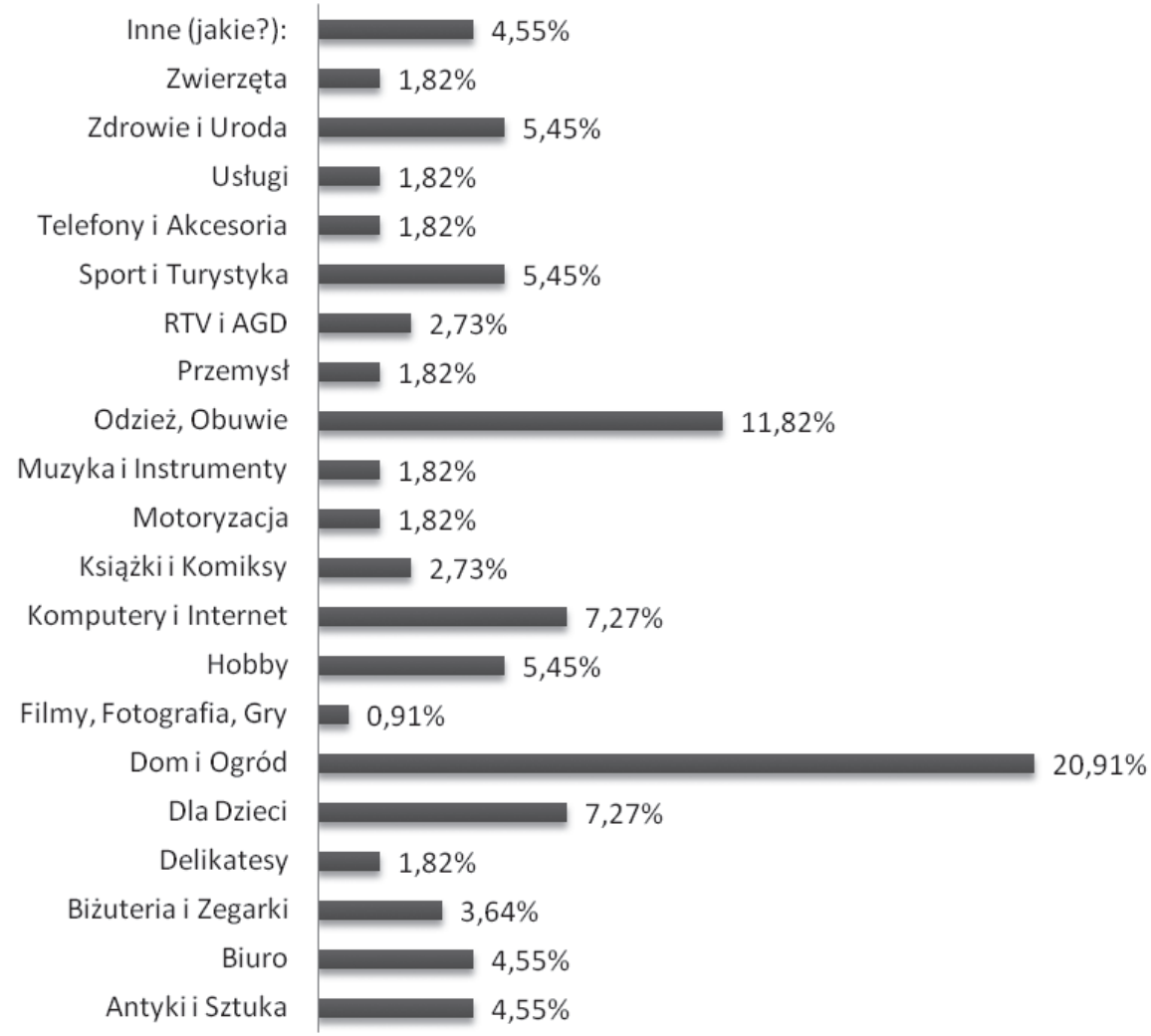

Wykres 2. Polskie e-sklepy - podział na branże Źródło: opracowanie własne

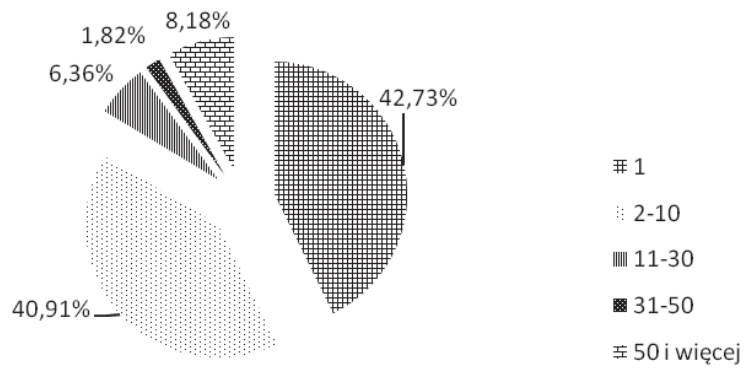

Wykres 3. Zatrudnienie w polskich sklepach internetowych Źródło: opracowanie własne 


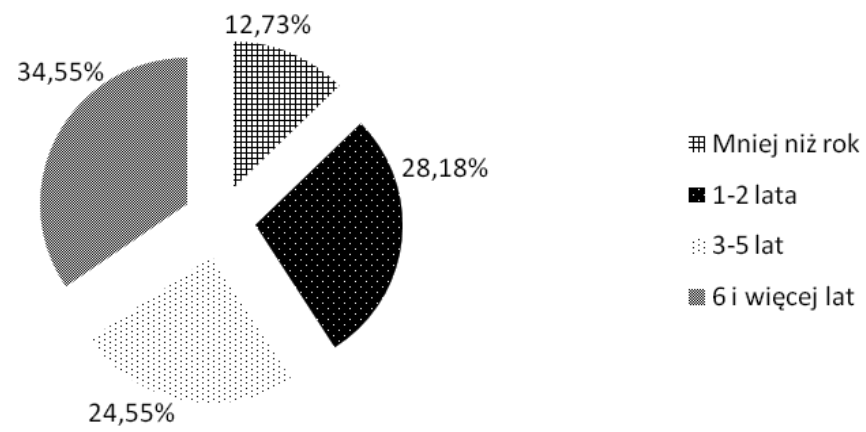

Wykres 4. Okres funkcjonowania e-sklepów Źródło: opracowanie własne

Z badania wynika, iż większość polskich e-sklepów działa od ponad 6 lat (wykres 4). Taka informacja pozwala stawiać hipotezę, że polski rynek e-commerce się rozwija, bowiem druga co do liczebności grupą są sklepy młode - prawie co trzeci ma nie więcej niż 2 lata, a ponad $12 \%$ to sklepy działające nie dłużej niż rok. Co czwarty sklep funkcjonuje od 3 do 5 lat.

\section{Zaopatrzenie i magazynowanie}

Przytłaczająca większość e-sklepów (80\%) ma w swojej ofercie ponad 100 produktów, ok. $11 \%$ posiada w asortymencie od 50 do 100 produktów, a ponad $7 \%$ nie więcej niż 50 . Prawie $2 \%$ sklepów oferuje mniej niż 10 produktów (wykres 5).

W celu sprawnej obsługi, a co za tym idzie, szybkiej wysyłki towaru do klienta przy tak licznej ofercie sklepów, muszą one regularnie uzupełniać swój asortyment, przy czym prawie co trzeci sklep zaopatruje się kilka razy w miesiacu. $22 \%$ pytanych uzupełnia asortyment codziennie i sa to sklepy o asortymencie ponad 100 towarów. Prawie co czwarty sklep dokonuje własnych zakupów przynajmniej raz w tygodniu. Raz w miesiącu uzupełnia towar $9 \%$ badanych, a jeszcze rzadziej $16 \%$, jednak $w$ tej grupie znalazło się $80 \%$ sklepów z asortymentem poniżej 50 produktów (wykres 6).

Jedna trzecia sklepów działających w sieci dokonuje własnych zakupów przez Internet (wykres 7). Z badań wynika jednak, że połowa sklepów zaopatruje się bezpośrednio u producentów swoich towarów. Jako inne formy zamówień wskazano skup towaru oraz własna produkcję (dotyczy to firm, które w swoim e-sklepie sprzedaja własne produkty). Z formy skupu korzystaja sklepy z branży antyki i sztuka, co tłu- 


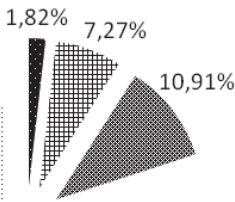

1-10

\#11-50

: $51-100$

$80,00 \%$

$100 \mathrm{i}$ więcej

Wykres 5. Asortyment polskich sklepów internetowych Źródło: opracowanie własne

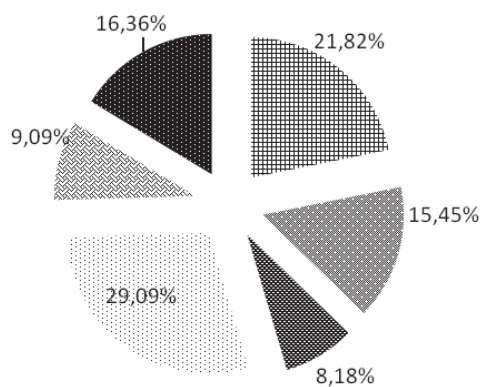

\# Codziennie Kilka razy w tygodniu

饠 Raz w tygodniu

Kilka razy w miesiącu

Raz w miesiącu

혈 Rzadziej niż raz w miesiącı

Wykres 6. Częstotliwość uzupełniania asortymentu przez polskie e-sklepy Źródło: opracowanie własne

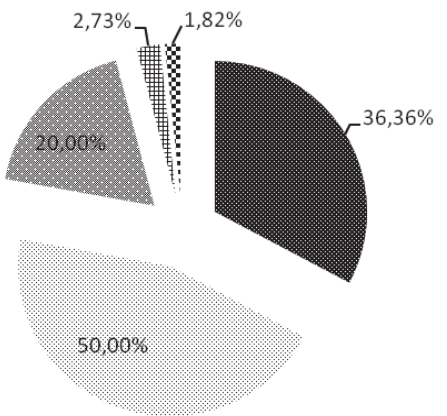

Zamówienia przez Internet

. Zakupy bezpośrednie u producenta

- Zakupy u pośrednika (hurt)

\# Produkcja własna

a Skup

Wykres 7. Formy zamówień wykorzystywanych przez polskie sklepy internetowe Źródło: opracowanie własne 
maczy taką formę zakupów. 5,71\% sklepów wskazało na wszystkie trzy formy zamówień: internetowe, u producenta i w hurcie.

Analizy wykazały, że polskie sklepy internetowe zaopatruja się głownie na rynku krajowym - takiej odpowiedzi udzieliło ponad $87 \%$ respondentów. Na rynkach zagranicznych kupuje prawie $45 \%$, a co trzeci sklep korzysta z obu rozwiązań. Ponad połowa badanych dokonuje zakupów wyłącznie u polskich przedsiębiorców, natomiast 13\% importuje towary z zagranicy (wykres 8).

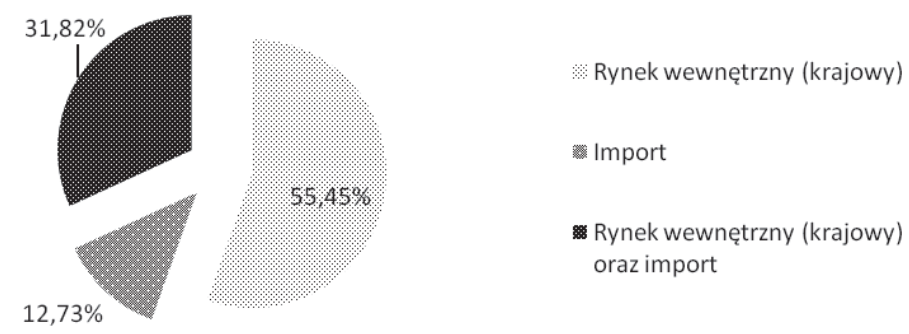

Wykres 8. Rynki zaopatrzenia polskich e-sklepów

Źródło: opracowanie własne

Wszystkie sklepy, które współpracuja z ponad 50 dostawcami, mają w ofercie ponad 100 produktów (wykresy 9 i 10). Najliczniejsza grupę, bo nieco ponad 37\% pytanych, tworza sklepy mające nie więcej niż 5 dostawców, z czego aż 56\% może pochwalić się asortymentem większym niż 100 produktów, a prawie 22\% mieści się w przedziale 51-100 pozycji towarowych. Niecałe $20 \%$ sklepów mających do 5 dostawców posiada w ofercie więcej niż 10 produktów, ale mniej niż 50. Połowa sklepów z asortymentem do 10 produktów współpracuje z nie więcej niż 5 dostawcami, co w tej grupie stanowi $2,44 \%$. Co piąty sklep zaopatruje się u 6-10 dostawców, 12,73\% badanych u 11-20, natomiast 14,5\% sklepów ma pomiędzy 21 a 50 dostawców.

Ponad 99\% respondentów deklaruje, że powtarza zakupy u tych samych dostawców. Niewielki odsetek niepowtarzających zakupów to sklepy z branży muzyka i instrumenty (wykres 11). Powtarzalność zakupów wynika w głównej mierze z cen zakupu - taką odpowiedź zaznaczyło ponad $60 \%$ ankietowanych. Na drugim miejscu znalazła się solidność dostawcy - wskazało ja 55\%. Jako kolejne powody wymieniono: przyzwyczajenie do zakupów u dostawcy oraz jego terminowość (wykres 12). 


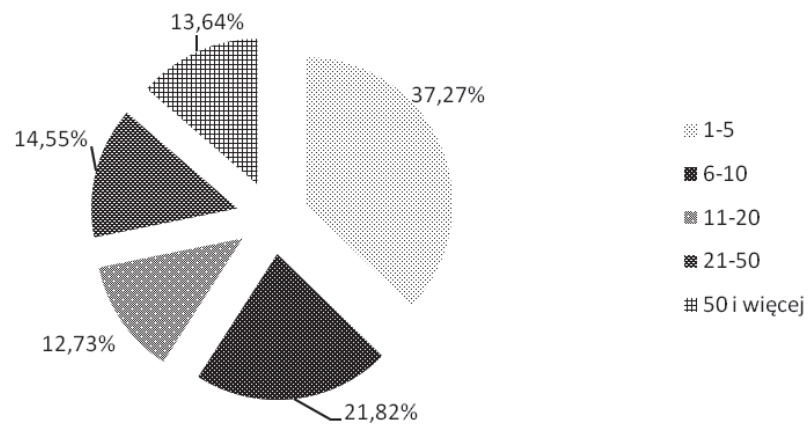

Wykres 9. Liczba dostawców polskich sklepów internetowych Źródło: opracowanie własne

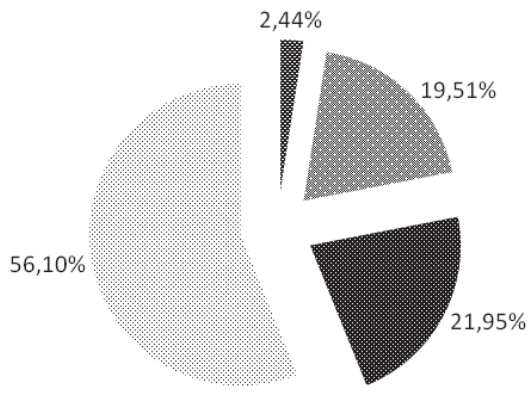

舜 1-10

ㄴ.w $11-50$

51-100

100 i więcej

Wykres 10. Zależność między wielkością asortymentu a ilością dostawców polskich e-sklepów

Źródło: opracowanie własne

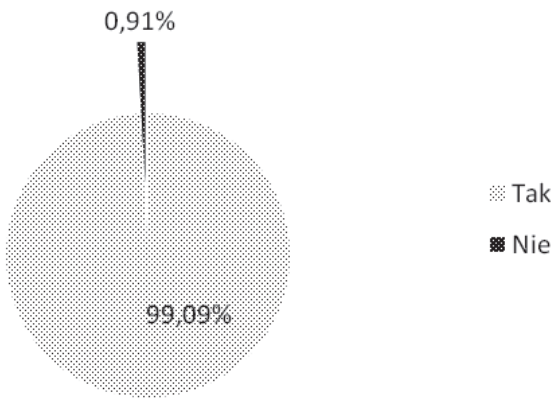

Wykres 11. Powtarzalność zakupów u tych samych dostawców przez polskie sklepy internetowe

Źródło: opracowanie własne 


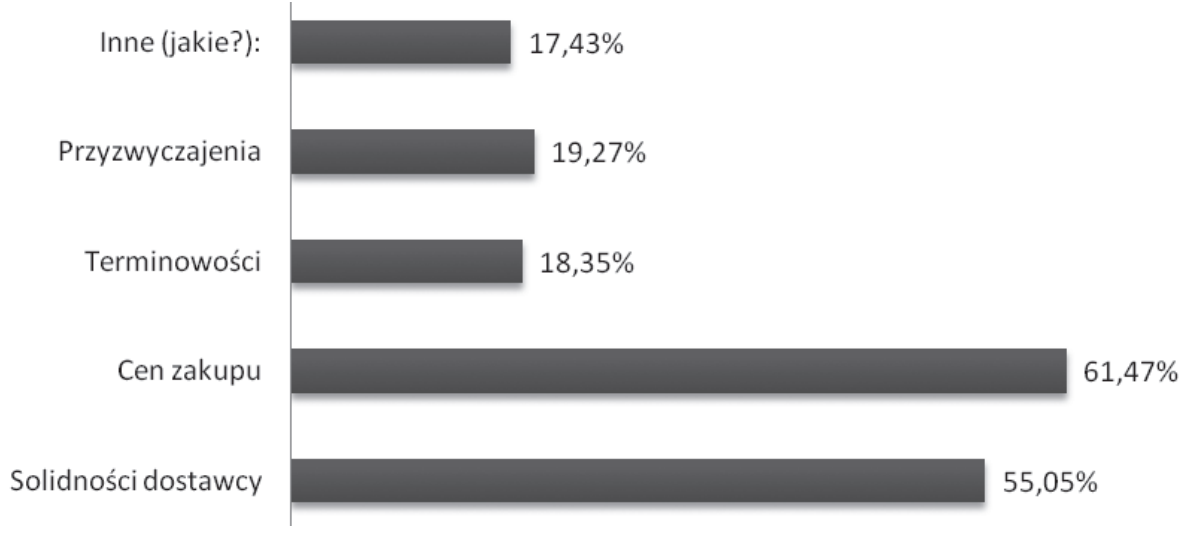

Wykres 12. Przyczyny powtarzalności zakupów u tych samych dostawców przez polskie sklepy internetowe

Źródło: opracowanie własne

17\% sklepów podało także inne powody, dla których powtarza zakupy u tych samych dostawców. Wśród nich ponad połowa wskazała na unikalność produktów oferowanych przez dostawcę. 36,84\% ankietowanych jest zwiazanych ze swoimi dostawcami umowami handlowymi. Po $5,26 \%$ badanych podało jako inny powód jakość produktów oraz przedstawicielstwa (wykres 13).

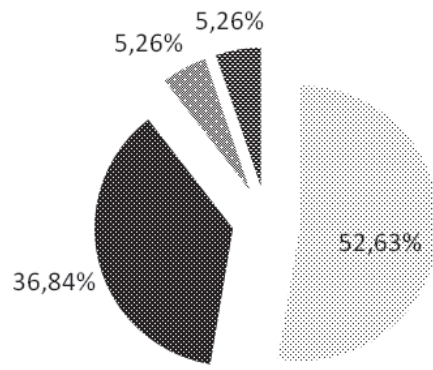

\author{
« Unikalność towaru \\ Umowy handlowe \\ Jakosc produktu \\ 営 Przedstawicielstwa
}

Wykres 13. Inne powody powtarzalności zakupów u tych samych dostawców przez polskie sklepy internetowe

Źródło: opracowanie własne

Biorąc pod uwagę wieloletnią współpracę e-sklepów ze swoimi dostawcami, naturalne wydaje się tworzenie relacyjnego charakteru współpracy między kontrahentami (wykresy 14 i 15). Spośród 53,64\% sklepów współpracujących ze swoimi głównymi dostawcami od ponad 3 lat, 


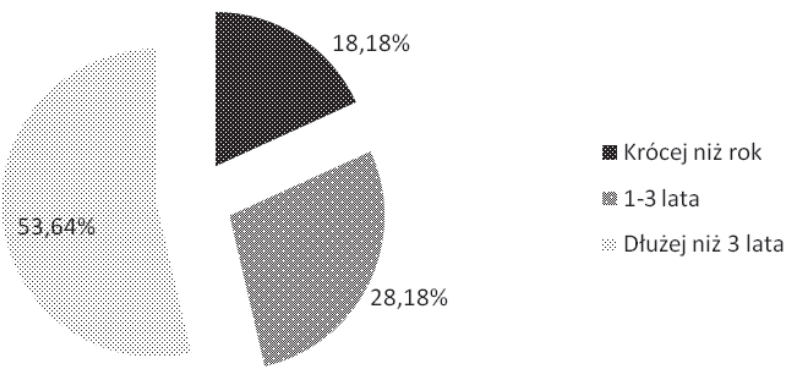

Wykres 14. Długość współpracy polskich sklepów internetowych z kluczowymi dostawcami

Źródło: opracowanie własne

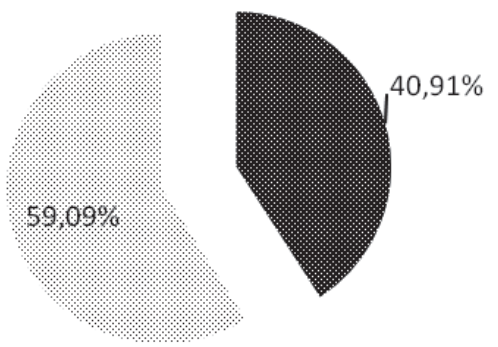

Transakcyjny

Relacyjny (tworzenie więzi)

Wykres 15. Charakter współpracy polskich e-sklepów z dostawcami Źródło: opracowanie własne

ponad $71 \%$ utrzymuje $\mathrm{z}$ nimi bliższe kontakty. W grupie sklepów powtarzających zakupy od roku do trzech lat znalazło się $28 \%$ pytanych, z których połowa zadeklarowała tworzenie więzi ze swoim dostawca. Jedynie co trzeci sklep zaopatrujący się w tym samym miejscu od niecałego roku deklarował relacyjny charakter współpracy z dostawca.

Bliższa współpraca między sklepem internetowym a jego dostawca przejawia się głównie, bo w 72\% przypadków, specjalnym traktowaniem, takim jak upusty czy odroczony termin płatności (kredyt kupiecki). Dwie trzecie sklepów utrzymuje z dostawca regularne kontakty, a co czwarty zadeklarował, że relacyjny charakter współpracy przejawia się regularnymi spotkaniami kontrahentów (wykres 16).

W czterech na dziesięć przypadków mamy do czynienia zarówno ze specjalnym traktowaniem, jak i utrzymywaniem regularnych kontaktów. Nieco ponad $12 \%$ respondentów regularnie się kontaktuje i spotyka z przedstawicielami dostawcy, natomiast w co dziesiatym przypadku mamy do czynienia ze spotkaniami i specjalnym traktowaniem. 
Specjalnym traktowaniem

Spotkaniami

Utrzymywaniem regularnych kontaktów

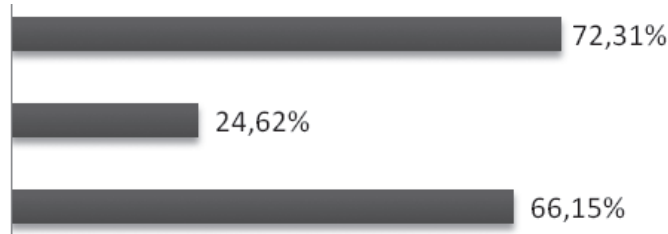

$66,15 \%$

Wykres 16. Przejawy relacyjnego charakteru współpracy między dostawca a e-sklepem Źródło: opracowanie własne

Na początku 2012 r. 23,64\% sklepów nie posiadało magazynów (wykres 17). Największy odsetek sklepów dysponuje niedużym magazynem do $100 \mathrm{~m}^{2}$, z czego ponad $12 \%$ ma symboliczny magazyn zajmujący nie więcej niż $10 \mathrm{~m}^{2}$ powierzchni. Prawie $12 \%$ ankietowanych wskazało, że posiada magazyn wielkości $101-500 \mathrm{~m}^{2}$, a co piąty sklep korzysta z bardzo dużych magazynów o powierzchni ponad $500 \mathrm{~m}^{2}$.

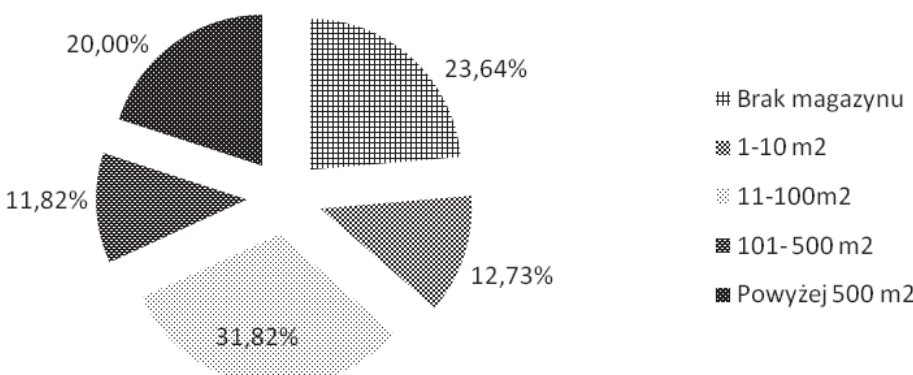

Wykres 17. Wielkość magazynów polskich sklepów internetowych Źródło: opracowanie własne

Wielkość magazynu jest skorelowana z liczbą oferowanych produktów. 95\% sklepów dysponujących dużym magazynem, powyżej 500 $\mathrm{m}^{2}$, jednocześnie ma $\mathrm{w}$ ofercie ponad 100 rożnych produktów, a 77\% obsługuje miesięcznie ponad 200 zamówień.

Spośród sklepów posiadających magazyn blisko $87 \%$ ma go na własność (wykres 18). Wynajmuje magazyn ponad $28 \%$ respondentów, zaś $13,10 \%$ posiada zarówno własny, jak i wynajmowany magazyn. W ostatniej grupie połowa sklepów, co wydaje się naturalne, może pochwalić się ponad 500-metrowym magazynem. 


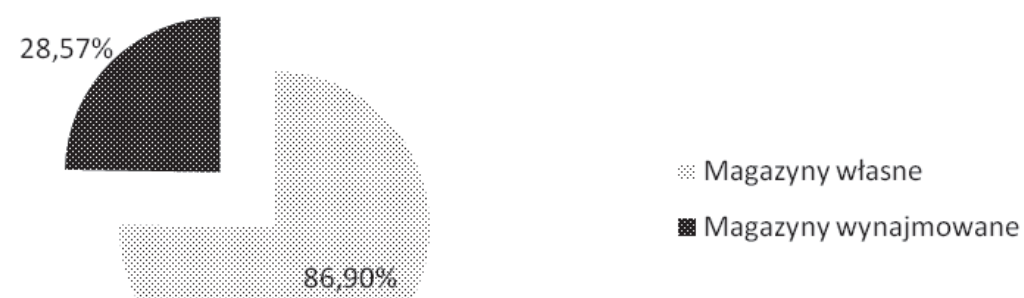

Wykres 18. Formy własności magazynów polskich e-sklepów Źródło: opracowanie własne

\section{Płatności}

Chcąc wyjść naprzeciw zapotrzebowaniom klientów, polskie sklepy internetowe oferuja szeroką gamę możliwości zapłaty - od przelewów bankowych i kart płatniczych, poprzez szybkie e-przelewy, po gotówkę. Dla klienta najważniejsze jest, aby metody płatności wykorzystywane w sektorze e-handlu były niezawodne i bezpieczne, a także zapewniały jak najszybszy czas obsługi.

Najpowszechniejszym sposobem płatności jest przelew bankowy na konto sklepu, udostępniany przez 95\% ankietowanych. Ten sposób jest wybierany przez klientów w blisko trzech na cztery przypadki (wykresy 19 i 20). O połowę mniejszą popularnościa cieszą się płatności za pobraniem, oferowane w ośmiu na dziesięć sklepów. Tak duże zainteresowanie tą forma zapłaty za towar może świadczyć o ciagłym braku zaufania do zakupów w sieci, mimo ich rosnącej popularności. Klienci wybierając płatność za pobraniem, zapewniaja sobie poczucie bezpieczeństwa, gdyż moga obejrzeć towar w obecności kuriera zanim za niego zapłaca.

Podobną forma do płatności za pobraniem jest płatność przy odbiorze. Sądząc po wynikach, można postawić hipotezę, że co najmniej trzy czwarte sklepów działających w Internecie posiada także tradycyjny stacjonarny sklep, w którym można odebrać zakupiony towar. Takie rozwiązanie nie cieszy się jednakże dużą popularnościa, ze względu na słabo rozwinięta sieć sklepów stacjonarnych.

40\% e-sklepów daje możliwość zapłaty kartą płatniczą bądź kredytowa, z czego korzysta co dziesiąty kupujący. Sprzedaż na raty jest dostępna w 7\% przypadków, jednak cieszy się mała popularnością (2\%). Mikropłatności w formie SMS-ów oferuja sklepy sprzedające w sieci 


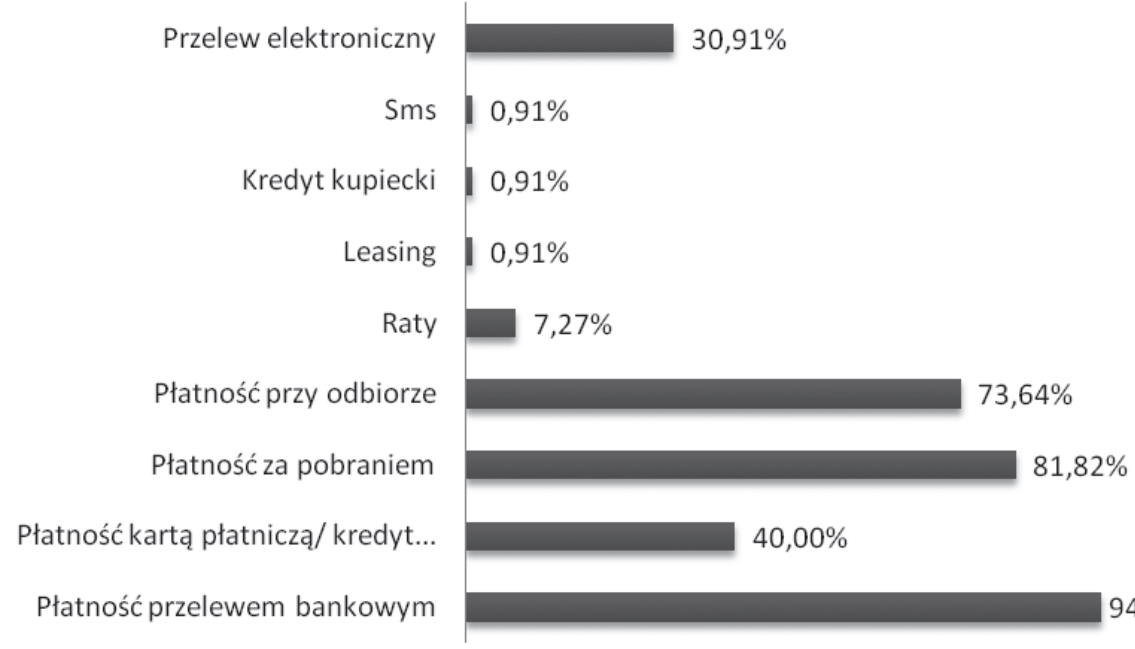

Wykres 19. Formy płatności udostępniane przez polskie e-sklepy

Źródło: opracowanie własne

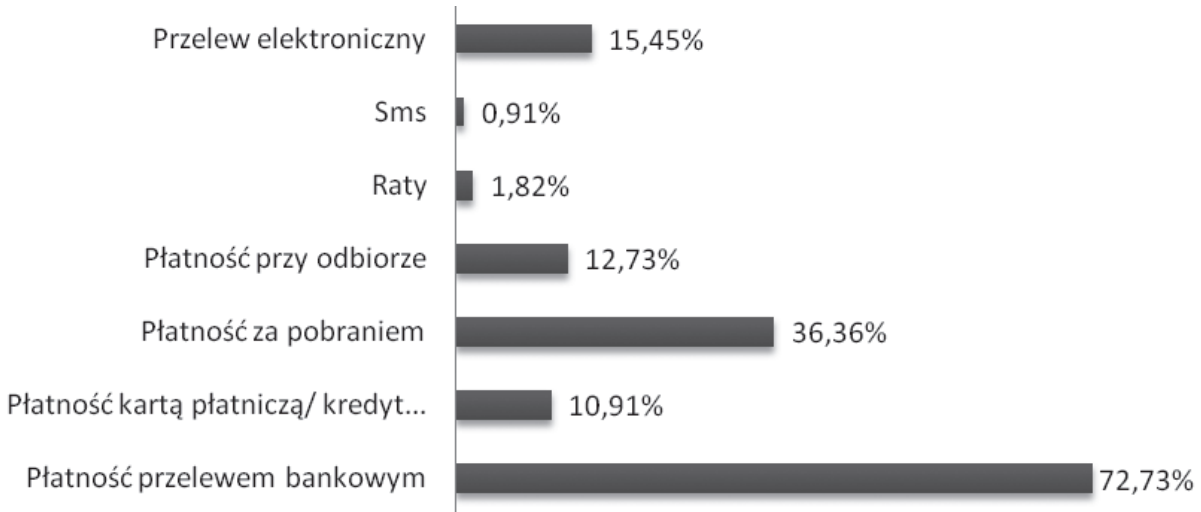

Wykres 20. Popularność form płatności w polskich sklepach internetowych

Źródło: opracowanie własne

utwory muzyczne i pozwalające ściągnąć utwór bezpośrednio ze strony internetowej po wpisaniu kodu otrzymanego w odpowiedzi na SMS.

Warto zwrócić uwagę, iż tradycyjne przelewy na konto sa wypierane przez szybkie e-przelewy. Klienci sklepów internetowych poszukują nowych możliwości realizacji płatności, pozwalających zapłacić natychmiast po dokonaniu zakupu, bez ponoszenia dodatkowych kosztów transakcji. W Polsce dostępnych jest już kilka rozbudowanych i wyspecjalizowanych serwisów płatności internetowych, jednak nie wszystkie 
banki z nimi współpracują. Przelew elektroniczny możliwy jest w co trzecim e-sklepie i w połowie przypadków już stał się najpopularniejszy.

Połowa udziałów w rynku przypadła spółce PayU, właścicielowi platnosci.pl działających do niedawna jako osobny serwis e-finansów. Systemy stworzone i obsługiwane przez PayU S.A. ${ }^{102}$ to:

- www.payu.pl - oferta dla użytkowników indywidualnych (konto PayU),

- www.payu.pl/sklepy - oferta dla sklepów internetowych (dawne platnosci.pl),

- www.paygsm.pl - doładowania telefonów komórkowych,

- www.placezallegro.pl - obsługa transakcji na platformie aukcyjnej Allegro.

W więcej niż jednym na cztery przypadki sklepy internetowe oferuja szybki przelew dzięki serwisowi PayPal. 15\% sklepów współpracuje z serwisem Przelewy24, a prawie 9\% korzysta z usług finansowych Dotpay (wykres 21).

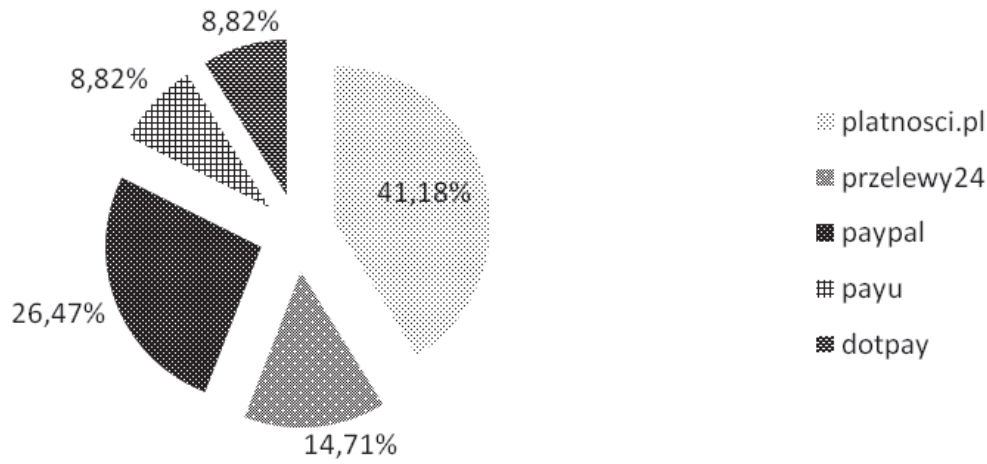

Wykres 21. Oferowane przez polskie sklepy internetowe serwisy elektronicznych przelewów

Źródło: opracowanie własne

Za udziałami rynkowymi kroczy popularność serwisów e-płatności (wykres 22). W sześciu na dziesięć przypadków kupujący wybieraja usługi PayU (licząc łącznie z dawnym serwisem platnosci.pl). Nieco po-

1025 maja 2005 r. na platformie Allegro, PayU (w tamtym czasie będące jeszcze częścią PAYBACK Sp. z o.o.) rozpoczęło procesowanie płatności online. Formalnie PayU S.A. została utworzona w listopadzie 2006 r. w celu przejęcia obsługi systemów płatności internetowych wydzielonych z PAYBACK Sp. z o.o. Celem spółki jest integracja istniejących i tworzenie nowych usług w zakresie płatności online oraz dostarczenie narzędzi ułatwiających działalność handlową w Internecie, za: www.payu.pl/informacje-ogolne,1732.html [z dn. 11.10.2012]. 


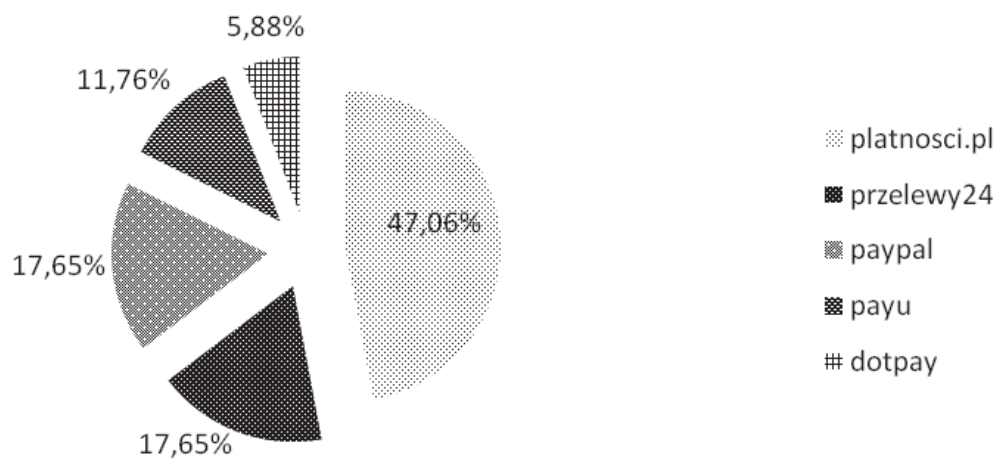

Wykres 22. Popularność serwisów przelewów elektronicznych w Polsce Źródło: opracowanie własne

nad 17\% korzysta z rozwiązania Przelewy24. Tyle samo respondentów zaznaczyło serwis PayPal. Najmniejszą popularnością cieszą się płatności w Dotpay, który wskazało 6\% ankietowanych.

Należy podkreślić, że wspomniane serwisy obsługują także płatności kartami kredytowymi i płatniczymi, dlatego gdyby zsumować wyniki popularności szybkich przelewów internetowych oraz płatności karta, to okazałoby się, że serwisy e-finansowe zyskały już 25\% udziałów w rynku.

\section{Dystrybucja i dostawa}

Internet umożliwia e-sklepom szeroki wachlarz możliwości prezentacji swojej oferty, poczynając od własnej strony internetowej, a na pasażach i katalogach skończywszy (wykres 23).

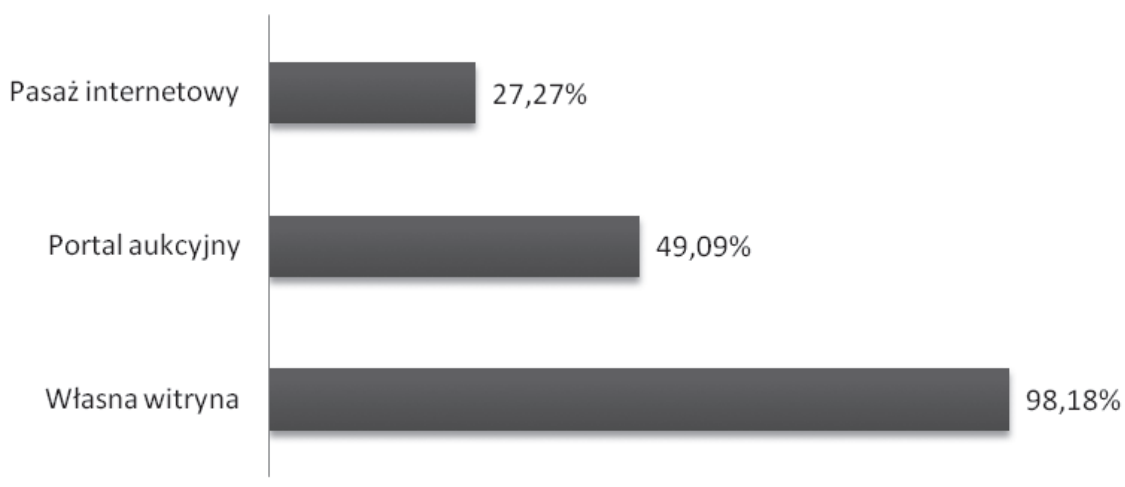

Wykres 23. Formy prezentacji oferty polskich e-sklepów

Źródło: opracowanie własne 
Jak na sklep internetowy przystało, prawie każdy z nich posiada własna witrynę internetowa. Połowa sprzedaje produkty na serwisach aukcyjnych, a każdy sklep korzysta z serwisu Allegro.pl. W pasażach i katalogach internetowych reklamuje się ponad $27 \%$ sklepów handlujących w sieci.

Badania wykazały, że e-sklepy stosuja wiele rozwiązań. Dystrybucję wyłącznie poprzez własna e-witrynę prowadzi $44,5 \%$ pytanych, a $1 \%$ sprzedaje tylko na Allego.pl. Co piaty sklep wykorzystuje wszystkie trzy sposoby dystrybucji. Najpopularniejszym połaczeniem sposobów prezentacji własnej oferty jest strona internetowa i portal aukcyjny. Z takiego rozwiązania korzysta co najmniej $27 \%$ respondentów. Nieco ponad 6\% łączy dystrybucję poprzez własną e-stronę i pasaż internetowy. Niespełna $1 \%$ sklepów nieposiadających własnej witryny prowadzi handel na portalu aukcyjnym i w pasażu (wykres 24).

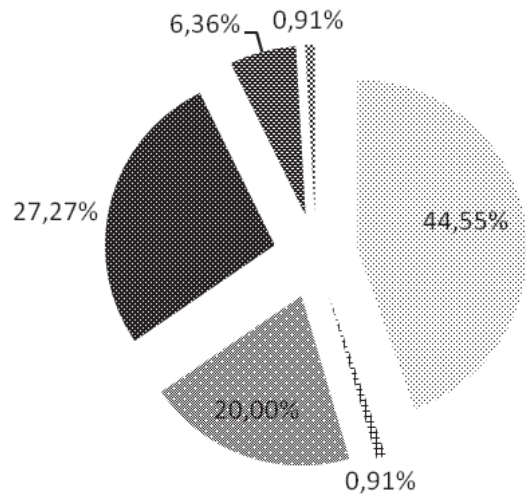

Wyłącznie witryna własna
Wyłącznie portal aukcyjny
Witryna własna+portal
aukcyjny+pasaż internetowy
aukcyjny
Witryna własna+ pasaż
internetowy
: Portal aukcyjny+pasaż
internetowy

Wykres 24. Sposoby dystrybucji internetowej wykorzystywane przez polskie sklepy internetowe

Źródło: opracowanie własne

Spośród internetowych sklepów handlujących na Allegro.pl, ponad $7 \%$ prezentuje swoje towary na portalu Ebay, a po 5,5\% ankietowanych korzysta również z serwisów Świstak i Aukcjusz (wykres 25).

Większość (90\%) polskich sklepów internetowych oferuje swoim klientom dostawę towaru kurierem (wykres 26). Przesyłkę pocztowa udostępnia wciąż ponad $61 \%$ ankietowanych. Tak wysoki wynik może być spowodowany, po pierwsze, powszechnością usług pocztowych oraz przyzwyczajeniem Polaków do tradycyjnej poczty, a po drugie, usługi pocztowe, szczególnie w przypadku małych, ekonomicznych przesyłek, które można wysłać np. w formie listu w kopercie bąbelkowej, są o wiele tańsze w porównaniu z przesyłką kurierska. 94\% ankietowanych ofe- 


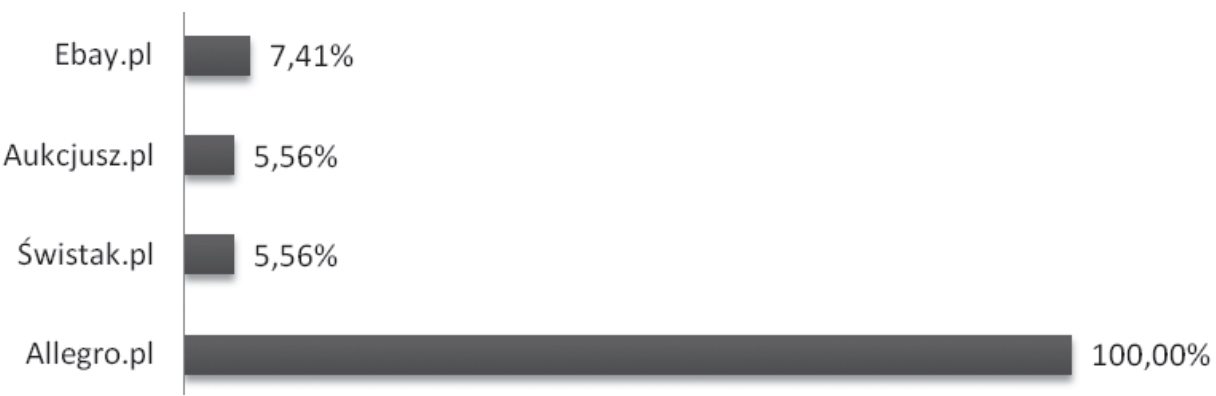

Wykres 25. Portale aukcyjne, na których handlują polskie e-sklepy Źródło: opracowanie własne

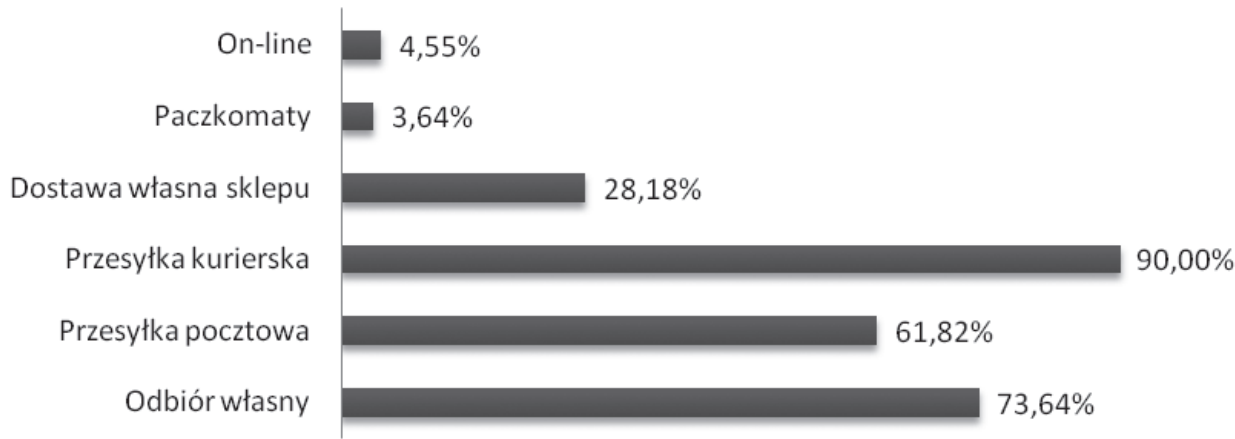

Wykres 26. Formy dostawy towaru oferowane przez polskie sklepy internetowe Źródło: opracowanie własne

rujących usługi pocztowe współpracuje także z firmami kurierskimi. Blisko trzy czwarte respondentów oferuje możliwość osobistego odbioru zakupionego towaru i, mimo że nie cieszy się on największą popularnością ze względu na wspominana już słabo rozwinięta sieć fizycznych punktów, jest to najbezpieczniejsza metoda odbioru towaru i jednocześnie najtańsza, ponieważ nie wiąże się z dodatkowymi kosztami obciążającymi klienta. Ponadto wynik ten potwierdza identyczny odsetek sklepów dających możliwość zapłaty przy odbiorze. W odniesieniu do wszystkich czterech wymienionych form odbioru przesyłki, $12 \%$ sklepów oferuje wszystkie możliwości. Co trzeci sklep dostarcza towar do klienta własnym transportem. Wśród innych form dostawy pytani wymienili paczkomaty ${ }^{103}$ i dostawę online.

${ }^{103}$ Paczkomaty InPost to system skrytek pocztowych, służący do odbierania paczek 24 godziny na dobę przez 7 dni w tygodniu. Osoba robiąca zakupy przez Internet po zamówieniu przesyłki do Paczkomatu InPost otrzymuje SMS i e-mail z kodem odbioru. Aby odebrać 
Klienci najchętniej wybieraja przesyłki kurierskie ze względu na dużo krótszy czas oczekiwania na przesyłkę w porównaniu do usług tradycyjnej poczty oraz mniejsze prawdopodobieństwo zgubienia lub uszkodzenia towaru. Preferuja ten sposób dostawy także w przypadku dużych paczek, ze względu na porównywalne koszty dodatkowo obciążające kupującego. Tradycyjna przesyłka pocztą cieszy się popularnościa w co trzecim sklepie, a o połowę mniejszą może się pochwalić odbiór własny i dostawa własna sklepu. Identyczny wynik popularności $(4,55 \%)$, jak i dostępności uzyskała dostawa przez Internet, oferowana przez sklepy z branży komputery, usługi, książki i muzyka. Co istotne, sklepy te oferują wyłącznie tę formę dostawy (wykres 27).

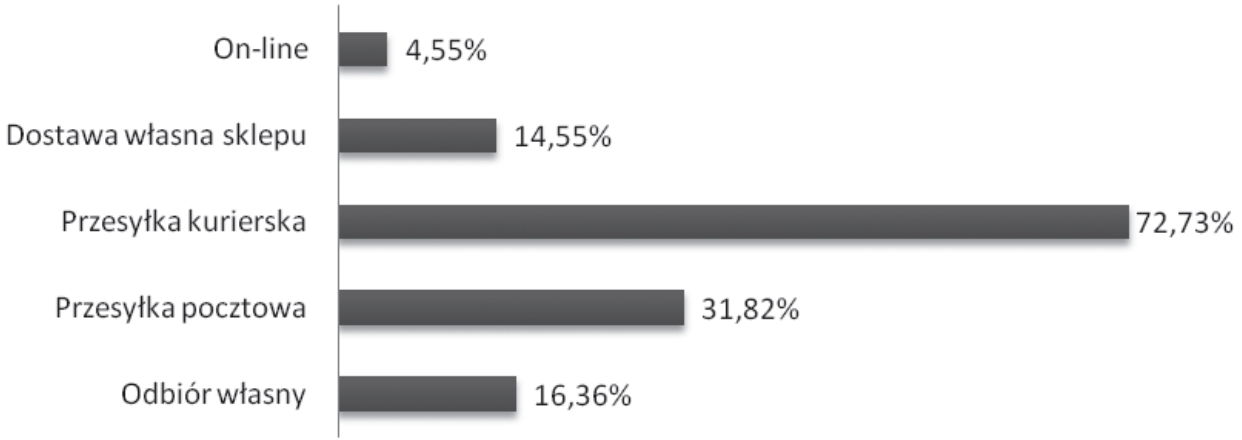

Wykres 27. Popularność form dostawy w polskich e-sklepach

Źródło: opracowanie własne

Spośród 94,5\% sklepów oferujących inne formy dostawy niż wyłącznie dostawa internetowa oraz dostawa własna, połowa współpracuje z Pocztą Polską (wykres 28). Wśród prywatnych firm kurierskich miejsce lidera zajał UPS z wynikiem 37,5\%, a zaraz za nim uplasowała się firma DPD, z która współpracuje co trzeci sklep. Na trzecim miejscu znalazł się DHL z wynikiem blisko $28 \%$. Co dziesiąty sklep dostarcza towary za pośrednictwem General Logistics. Po 8,65\% uzyskały Siódemka i InPost. Wśród firm kurierskich wskazanych w opcji "Inne” prawie $3 \%$ sklepów wymieniło K-EX, a 2\% firmę Schenker. Niespełna 1\% sklepów współpracuje z firmami Opek oraz Pekaes.

przesyłkę, wystarczy wpisać na panelu Paczkomatu InPost numer telefonu komórkowego oraz otrzymany kod odbioru, a skrytka z oczekiwana przesyłką otworzy się. W ciągu 2 dni roboczych od momentu nadania paczki przesyłka znajduje się w paczkomacie. Odbiór paczki jest możliwy o dowolnej porze dnia i nocy, za: www.paczkomaty.pl/o_usludze,12.html [z dn. 12.02.2012]. 


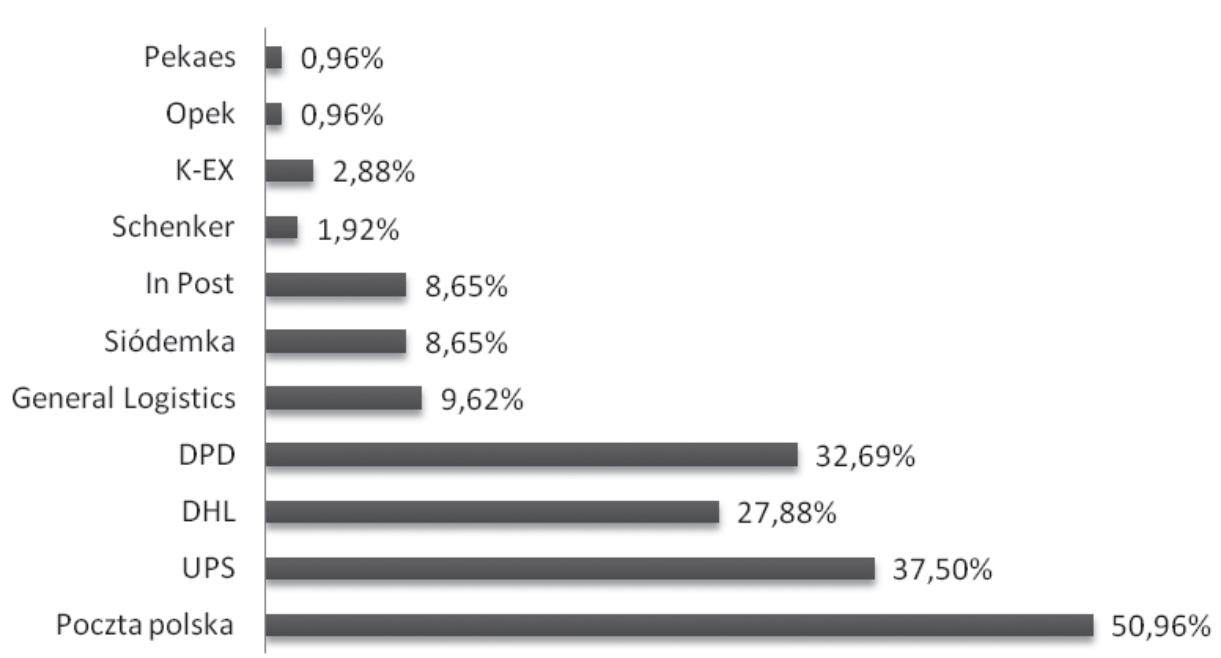

Wykres 28. Firmy kurierskie, z usług których korzystaja polskie e-sklepy Źródło: opracowanie własne

Ponad 65\% ankietowanych nawiązało współpracę z więcej niż jedną firmą logistyczna, a 17\% korzysta z usług co najmniej trzech operatorów.

\subsubsection{Obsługa klienta}

Równo połowa polskich e-sklepów obsługuje miesięcznie mniej niż 50 zamówień, jednak taki wynik nie dziwi, gdyż blisko $62 \%$ z nich istnieje ok. 2 lat. Znacznie lepsze wyniki osiaggają sklepy o dłuższym stażu, istniejace na rynku od co najmniej 3 lat. $91 \%$ z nich może się pochwalić liczbą 200 i więcej zamówień miesięcznie. Co piąty sklep obsługuje od 50 do 200 zamówień. 14,5\% respondentów znalazło się w przedziale 200-500 klientów na miesiąc, a o 1\% więcej może pochwalić się największymi obrotami - ponad 500 obsłużonych klientów (wykres 29).

Coraz większe zainteresowanie Polaków e-zakupami i zaufanie do nich potwierdzaja wyniki dotyczące odsetka stałych klientów sklepów internetowych (wykres 30). Aż 44\% ankietowanych ma od 1 do $10 \%$ stałych klientów. U jednego na pięć sklepów powtarza zakupy 11-30\% klientów. Nawet połowa klientów powtarza zakupy w ponad $6 \%$ e-sklepów. Drugie tyle sklepów może pochwalić się powtarzalnością zakupów na poziomie $51-70 \%$. Największy odsetek stałych klientów, wynoszący do $90 \%$, zadeklarowało $8 \%$ pytanych. Do kolejnych zakupów moga zachęcić stosowane przez sklepy różne formy promocji (wykres 31). 


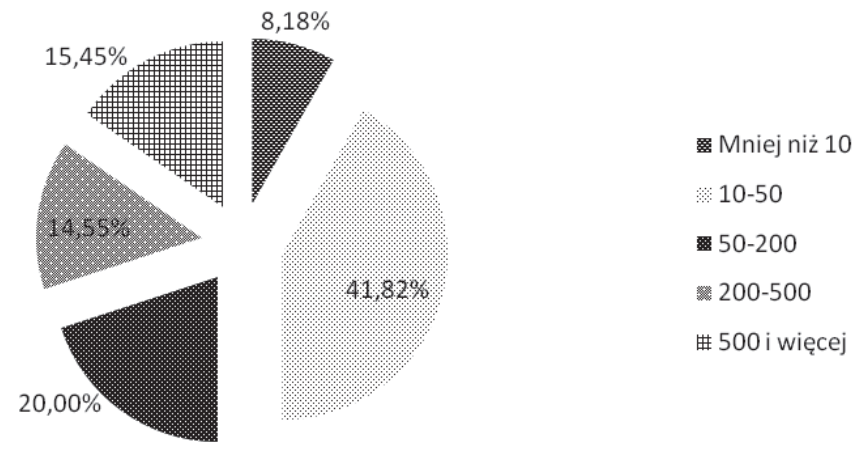

Wykres 29. Wielkość miesięcznych zamówień obsługiwanych przez polskie sklepy internetowe

Źródło: opracowanie własne
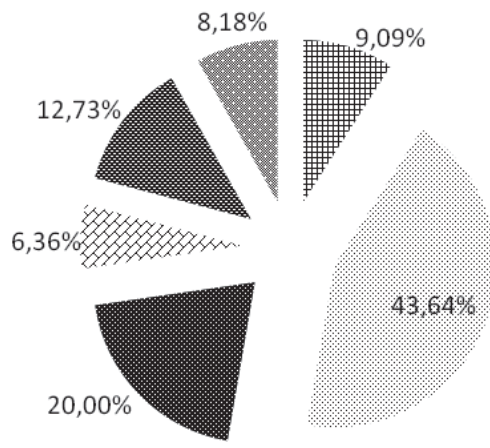

\# $0 \%$

$1-10 \%$

$11-30 \%$

$z 31-50 \%$

蹈 $51-70 \%$

1- $71-90 \%$

Wykres 30. Odsetek stałych klientów polskich e-sklepów

Źródło: opracowanie własne

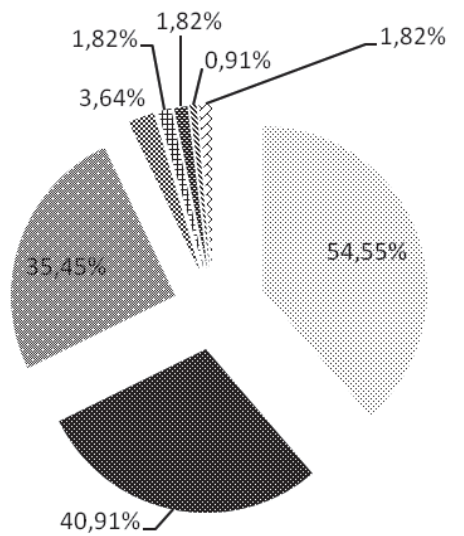
Darmowa dostawa przy zakupach powyżej pewnej wartości/ilości produktów
器 Upusty przy powtórnych zakupach
"Gratisy" dołączane do zakupów
\& Program lojalnosciowy
\# Darmowe probki
Możliwość negocjacji cen
$\mathbb{N}$ Kupony promocyjne
\%. Kody rabatowe

Wykres 31. Formy promocji oferowane przez polskie sklepy internetowe Źródło: opracowanie własne 
Blisko 55\% sklepów oferuje darmowe dostawy towaru przy zakupach powyżej pewnej wartości lub liczby produktów. $41 \%$ zachęca do powtórnych zakupów, udzielając $w$ takiej sytuacji upustów. Ponad jedna trzecia respondentów dołącza do zakupów gratisy. Ze wszystkich wymienionych form promocji klienci moga skorzystać u 19\% handlujacych w sieci. Taka sama liczba sklepów oferuje co najmniej dwa z trzech wyżej opisanych rozwiązań.

Respondenci, mając do dyspozycji odpowiedź „Inne”, wskazali również niewymienione $\mathrm{w}$ ankiecie formy promocji. Wśród takich odpowiedzi znalazł się m.in. program lojalnościowy (3,64\%), najczęściej polegający na zbieraniu punktów za każde zakupy i możliwości wymiany tych punktów na rabaty lub zapłaty punktami. Prawie $2 \%$ sklepów oferuje darmowe próbki dołączane do pierwszych zakupów lub wysyłane jeszcze przed pierwszym zakupem, możliwość negocjacji cen i kody rabatowe. Niespełna 1\% ankietowanych wskazało kody promocyjne.

\subsection{Podsumowanie}

Przedstawione dane statystyczne i wyniki badań potwierdzaja dynamiczny rozwój polskiego rynku e-commerce. Wpływ na to maja przede wszystkim użytkownicy Internetu. Powszechny dostęp do sieci powoduje przeobrażenia w społeczeństwie, które staje się społeczeństwem mobilnym. Współcześnie, by skorzystać z Internetu, nie jesteśmy już skazani wyłącznie na komputer - taką sposobność dają nam tablety, palmtopy czy nawet telefony komórkowe. Dzięki takim rozwiązaniom możemy korzystać z dobrodziejstw Internetu w każdym miejscu, o każdej porze. Klienci, uniezależnieni od godzin otwarcia sklepów i przymusu wychodzenia z domu, mając możliwość szybkiej dostawy produktów pod same drzwi, chętnie kupuja w sieci ze względu na wygodę, a także np. sposobność wysłania towaru jako prezentu dla osoby trzeciej.

Celem niniejszego rozdziału było kompleksowe przedstawienie narzędzi logistycznych, jakimi posługują się w Polsce sklepy internetowe. Rynek ten jest bardzo młody, przez co rozdrobniony, dlatego sklepy, walcząc o klienta, nie ograniczają się wyłącznie do sprzedaży poprzez jeden kanał internetowy. Pojedyncze sklepy łączą się w większe wirtualne organizacje, jak np. pasaże handlowe, reklamuja się we wszelkiego rodzaju katalogach, a także handluja na platformach aukcyjnych.

Badania wykazały, że szybkość dostarczenia zakupów do klienta zapewnia przede wszystkim bliska kooperacja sklepów z ich własnymi dostawcami i regularne uzupełnianie stanów magazynowych. Skle- 
py współpracują z wyspecjalizowanymi firmami kurierskimi i poczta, często nie ograniczając się do jednego operatora, lecz dając klientom możliwość wyboru sposobu dostawy. Rozwój elektronicznych systemów płatniczych także znacząco wpływa na skrócenie czasu dostawy i bezpieczeństwo transakcji. Zarówno sklep, jak i jego klient nie czekaja już na zaksięgowanie wpłaty na koncie sklepu, bo zapłata dokonuje się w czasie rzeczywistym natychmiast po złożeniu zamówienia. Poczucie bezpieczeństwa zapewnia e-klientom możliwość zwrotu towaru bez podania jakiejkolwiek przyczyny.

Jak wiadomo, pozyskanie nowego klienta jest siedmiokrotnie droższe od utrzymania dotychczasowego, dlatego obok narzędzi logistyki sklepy wykorzystują narzędzia marketingowe, takie jak: darmowe dostawy, upusty, darmowe próbki i gratisy czy programy lojalnościowe. W dobie rozwoju social media sklepy prowadza w sieci za pośrednictwem portali społecznościowych akcje promocyjne, w ramach których klienci moga otrzymać kody promocyjne i kupony rabatowe.

Zaprezentowane dane oddaja całościowy obraz logistyki polskiego e-handlu i pokazuja, jakie rozwiązania wdrażaja sklepy, aby pozyskać i utrzymać klienta, co decyduje o pozycji firmy na rynku. 